\title{
Evaluation of Anticonvulsants for Possible Use in Neuropathic Pain
}

\author{
A.M. Waszkielewicz*, A. Gunia, K. Słoczyńska and H. Marona \\ Department of Bioorganic Chemistry, Chair of Organic Chemistry, Faculty of Pharmacy, Jagiellonian University Medical College, 9 \\ Medyczna Street, 30-688 Krakow, Poland
}

\begin{abstract}
Neuropathic pain is a kind of pain related with functional abnormality of neurons. Despite large progress in pharmacotherapy, neuropathic pain is still considered an unmet need. Nowadays, there are few drugs registered for this condition, such as pregabalin, gabapentin, duloxetine, carbamazepine, and lidocaine. Among them, pregabalin, gabapentin and carbamazepine are well known antiepileptic drugs.

Among the group of new antiepileptic drugs, which are addressed to $1 \%$ of human world population suffering from seizures, it turned out that $30 \%$ of the seizures resistant to pharmacotherapy has not enough market to justify the costs of drug development. Therefore, it is already a phenomenon that researchers turn their projects toward a larger market, related with possible similar mechanism.

Anticonvulsant mechanism of action is in the first place among primary indications for drugs revealing potential analgesic activity. Therefore, many drug candidates for epilepsy, still in preclinical stage, are being evaluated for activity in neuropathic pain.

This review is focusing on antiepileptic drugs, which are evaluated for their analgesic activity in major tests related with neuropathic pain. Relation between structure, mechanism of action and result in tests such as the Chung model (spinal nerve ligation SNL), the Bennett model (chronic constriction injury of sciatic nerve CCI) and other tests are considered. The first examples are carbamazepine, gabapentin, and lacosamide as drugs well established in epilepsy market as well as drug candidates such as valnoctamide, and other valproic acid derivatives, novel biphenyl pyrazole derivatives, etc. Moreover, clinical efficacy related with listed animal models has been discussed.
\end{abstract}

Keywords: Allodynia, analgesic, anticonvulsant, CCI, epilepsy, hyperalgesia, neuropathic pain, preclinical, seizures, SNL.

\section{INTRODUCTION}

Neuropathic pain is a kind of pain caused by functional abnormality of neurons, related with their damage. Despite large progress in pharmacotherapy, neuropathic pain as an indication is still considered an unmet need, since $50 \%$ of patients suffer from the pain despite treatment [1]. Nowadays, there are few drugs registered for this condition, such as amitriptyline [2], pregabalin [3], gabapentin [4], duloxetine [5], carbamazepine [6], lidocaine [7], lamotrigine [8], and opioids [9]. Among them, pregabalin, gabapentin, carbamazepine, and lamotrigine are well known and well established antiepileptic drugs (AEDs). Furthermore, gabapentin is considered the leading drug in neuropathic pain treatment.

Among the group of new AEDs, which are addressed to $1 \%$ of human world population suffering from seizures, it turned out that $30 \%$ of the seizures resistant to pharmacotherapy has not enough market to justify the costs of drug development. Even though the number of epileptic conditions is still rising, as epileptogenesis becomes better understood, the new conditions such as myoclonic astatic seizures, Lennox-Gastaut syndrome, or severe myoclonic epilepsy in infancy, or even epilepsy in pregnancy or childhood are a difficult market to develop new drugs. Most recent AEDs have been developed through the Antiepileptic Drug Development Program (ADD) at National Institutes of Neurological Disorders and Stroke, (NINDS), National Institutes of Health (NIH), Rockville, MD, USA under supervision of prof. James P. Stables or with some support from the Institute [10].

Well known AEDs revealing certain mechanisms involved in the genesis and maintenance of hyperexcitability, are an important area of progress in the research and therapy of neuropathic pain. Currently, among primary indications for drugs revealing potential analgesic activity in neuropathic pain in the first place most often there is anticonvulsant mechanism of action. Therefore, many drug candidates for epilepsy, still in preclinical stage, are being evaluated for activity in neuropathic pain. Mechanisms of action represented

*Address correspondence to this author at the Department of Bioorganic Chemistry, Chair of Organic Chemistry, Faculty of Pharmacy, Jagiellonian University Medical College, 9 Medyczna Street, 30-688 Krakow, Poland; Tel: 0048 126205576; Fax: 0048 126205405; E-mail: awaszkie@cm-uj.krakow.pl by analgesic drugs effective in neuropathic pain are also typical in most cases of antiepileptic drugs:

- $\quad$ ion channel modulators (sodium, potassium, and calcium),

- $\operatorname{GABA}(\gamma$-aminobutyric acid) modulators,

- glutamate receptor modulators,

- monoamine modulators,

- cannabinoid receptor modulators,

- $\quad$ opioids, and

- topical capsaicin treatments.

Among the above mechanisms, the major ion channel modulators and GABA modulators are typical mechanisms of action of AEDs.

Neuropathic pain has been considered as a progressive nervous system disease in which spread of pain generating mechanisms is due to the biochemical reactions in the nervous system [11]. Some systemic reviews have drawn attention to new information of molecular, biochemical and neuroanatomical mechanisms of neuropathic pain which have identified a potential therapeutic target for the treatment of persistent pain.

Peripheral neuropathic pain may be caused by mechanical nerve injury, metabolic disease, neurotropic viral disease, neurotoxicity or tumor. Those factors may result in pathophysiological changes in peripheral as well as in central nervous system. Spinal cord injury, stroke or multiple sclerosis remain most common reasons of central neuropathic pain. Differentiation of the peripheral and central sites of the pain is possible considering only the etiology because those mechanisms are initiators of the cascade of changes in all parts of nervous system. Another possible etiology of persistent pain is related with inflammatory mechanisms but undoubtedly there is a fundamental difference in the neuronal pathways responsible for neuropathic and inflammatory pain so they remain distinct in terms of their eiology and clinical features [12]. Inflammation involves accumulation of endogenous factors (such as mast cells, basophils, platelets, macrophages, neutrophils, endothelial cells, keratinocytes, and fibroblasts) which can infiltrate the changed nerves. Additionally, nociceptors express one or more cell-surface receptors capable of responding to these agents, which together lead to enhancing excitability of the nerve fiber. Reducing inflammatory pain is 
commonly reached by inhibition of synthesis or accumulation of those pro-inflammatory factors. Another approach is to block the action at the nociceptor. The progress has been made in identifying new target molecules in possible therapeutic strategies of treating inflammatory pain. There are nerve growth factor (NGF), interleukin-1 $\beta$ (IL-1 $\beta$ ), IL-6, tumor necrosis factor $\alpha$ (TNF- $\alpha$ ) and transient receptor potential (TRP) cation channels among them are nociceptor channels responsible for sensitivity to heat - TRPV1 (also known as vanilloid receptor or capsaicin receptor) or chemical stimuli - TRPA1 [13].

Great progress has been also made in understanding mechanisms implicated in central site of neuropathic pain. Among others, alteration in glutamatergic neurotransmission/NMDA receptormediated sensitization, loss of GABAergic and glycinergic controls (disinhibition) and glial-neuronal interactions have been described [13]. Undoubtedly voltage-gated sodium channels $\left(\mathrm{Na}_{\mathrm{V}}\right)$, especially their specific isoforms $\left(\mathrm{Na}_{V} 1.1-\mathrm{Na}_{V} 1.9\right)$, constitute an attractive target in pharmacotherapy of neuropathic pain. It has been shown in both animal studies and human tissues that nerve injury induces dynamic regulation of sodium channel expression in dorsal root ganglion [14]. But still it is not clearly stated which sodium channel isoforms are responsible for human neuropathic pain syndromes. However, $\mathrm{Na}_{\mathrm{V}} 1.8$ and $\mathrm{Na}_{\mathrm{V}} 1.3$ are promising molecules [15]. Recent studies showed that T-type $\left(\mathrm{Ca}_{\mathrm{V}} 3\right)$ channels are also in interest as target molecules in neuropathic pain [16].

Neuropathic pain can be divided into three major disorders: diabetic neuropathic pain (DNP), post-herpetic neuralgia (PHN), and Human Immunodeficiency Virus-associated neuropathic pain (HIVNP). Approximately $20-24 \%$ of diabetes patients suffer from DNP [17]. Other neuropathies to be mentioned are trigeminal neuralgia, thalamic syndrome, phantom limb pain, tabetic pain, etc. The prevalence in the USA is $0.054 \%$ for DNP, and $0.185 \%$ for PHN [18].

Preclinical evaluating tests for neuropathic pain are based on mice or rats and involve surgery or chemical stimuli. Animal models of pain have been designed for proper evaluation of drug candidates for potential use in various pain types.The following list is limited to the kinds of assays which have been used for evaluation of antiepileptic drugs.

Tight Ligation of Spinal Nerves (SNL-Spinal Nerve Ligation), i.e. the Kim and Chung model, Chung model - the procedure involves spinal L5 or L5-L6 nerves ligation in rats; the test allows assessment of activity in alleviating mechanic allodynia and mechanic hyperalgesia, as well as thermal hyperalgesia. The pain is developed in the hind limb at the side of the ligation. The symptoms remain for 49 days and the test is concerned as a model for acute pain [19].

Loose Ligation of the Sciatic Nerve (CCI-chronic constriction injury), i.e. the Bennett and Xie model, Bennett model - the procedure is performed in rats and causes development of inflammation as a response to presence of the thread, which in turn leads to damage of the neuron and development of neuropathic pain. The phenomena related with the model are mechanic allodynia, mechanic hyperalgesia, and thermal hyperalgesia. The neuropathic pain is developed up till 2 weeks after the procedure. The CCI model is concerned as a test for chronic pain [19].

Streptozocin test - the test for diabetic neuropathy in mice or rats; the animals that have developed diabetes post streptozocin i.p.(intraperitoneal) administration, are administered a tested substance and response to nociceptive stimuli is observed [20].

Additionally, the formalin test is usually performed to study whether the compound possesses any analgesic activity. The test involves injection of formalin to a mouse or a rat paw which results in neuronal damage, exhibited by two phases of pain response: acute phase and inflammatory phase [21, 22].

As the tests used for verification of analgesic activity must induce pain in animals, in order to spare the animals, the negative controls are often represented by:

a group of animals which have received injection with placebo,

sham-operated rats (in the CCI and SNL models) - the animals have the nerve isolated but not ligated, or

the sensitivity is tested at the opposite side of the ligation.

Nociception is related with the following phenomena:

allodynia - pain caused by non-nociceptive stimulus, e.g. due to lowering sensitivity threshold of a receptor. Tactile allodynia occurs probably due to central changes triggered by increased activity of nociceptors but in contrast, more recent findings suggest that nociceptors are not required for the induction of mechanical hypersensitivity[23].

analgesia - lack of feeling pain in place of nociceptive stimulus;

anesthesia - lack of all perception types;

hyperalgesia - increased sensitivity to pain; the mechanism of hyperalgesia is probably connected with functions of thalamus, anterior cingulate cortex and central nucleus of the amygdala [23].

neuralgia - attacks of short time pain not related with any cause, without damage of the nervous system;

paresthesia - wrong perception of a pain stimulus.

The observed allodynia types in the models involve:

cold allodynia - response to ethyl chloride spray stimulation - the total time of licking the limb is added; or placing a drop of acetone on the foot and observing its withdrawal; acetone is placed 5 times, each time after a 5 min. break; the endpoint is the amount of acetone followed by withdrawal of the limb $* 100$,

tactile allodynia - response to touch by von Frey filaments respective to various strengths and masses; the endpoint is number of touches followed by withdrawal of the limb * 100.

The aim of this review is to show antiepileptic drugs which are evaluated for their analgesic activity in major tests related with neuropathic pain. Relation between structure, mechanism of action and result in tests such as the Chung model - the most popular test, the Bennett model and other tests are considered.

Moreover, some authors have approached similar reviews in the past $[12,13,23,24]$, however, large progress has been made in terms of knowledge underlying molecular and cellular mechanisms of disease development as well as possible mechanisms of action of potential drugs, and clinical efficacy of drugs.

\section{ANTIEPILEPTIC DRUGS AND THEIR EVALUATION FOR PAIN TREATMENT}

The currently used antiepileptic drugs have been secondarily evaluated in neuropathic pain models, which means that neuropathic pain is their second indication. This could be the reason why such compounds show modest efficacy in neuropathic pain. However, new drugs have some advantages, such as improved profile and pharmacokinetics and more favorable tolerability [25]. This is why this review is focused on comparison of the activity in epilepsy with activity in neuropathic pain in the same species and routes of administration. The drugs have been grouped with mechanisms of 
action and secondarily by structure similarities. The results presented in the text are summarized in Table $\mathbf{1}$.

\section{Ion Channel Modulators}

Ion channel modulators exhibit great potential in neuropathic pain. Lacosamide, which represents sodium channel blockers, has become very popular AED in the pain treatment [15]. However, retigabine - a potassium channel opener, also turned out to be active in pain models, as shown below. Other channels related with analgesic and anticonvulsant activity are calcium channels.

Voltage-gated sodium channels have been shown to play a critical role in neuropathic pain. Still, their non-specific inhibition is also a mechanism of action for the oldest antiepileptic drugs. Within the process of neuropathic pain formation, due to GDNF (glial cell derived neurotrophic factor) enhanced activity, voltagegated sodium channel $\left(\mathrm{Na}_{\mathrm{V}}\right)$ subtype 1.3 is induced, causing susceptibility to stimuli. Moreover, in the non-destructed part of the neuron $-\mathrm{Na}_{\mathrm{V}} 1.7$ and 1.8 channels are overexpressed [18]. This is why sodium channels are a promising target for drug candidates, however, for the ones that are selective enough. Recent studies have shown that by targeting specifically subtypes $\mathrm{Na}_{\mathrm{V}} 1.1$ and 1.2 a molecule can reduce seizures [26] and not neuropathic pain. Therefore, specificity towards $\mathrm{Na}_{V} 1.3,1.7$, and 1.8 versus $\mathrm{Na}_{\mathrm{V}} 1.1$ and 1.2 could differentiate between analgesics and antiepileptic drugs, respectively.

Inhibition of sodium channels is the mechanism seen for the very first antiepileptic drugs and for some novel drug candidates: carbamazepine, oxcarbazepine, lamotrigine, lacosamide, zonisamide, topiramate, and biaryl pyrazoles. Opening potassium channels is a main mechanism for retigabine, but the biaryl pyrazole derivative by Merck also exhibits some affinity. Calcium channels are influenced by zonisamide, topiramate, and the mentioned biaryl pyrazole derivative, and the $\alpha 2 \delta$ subunits of channels are inhibited by pregabalin and gabapentin.

\section{Carbamazepine and Oxcarbazepine}

Carbamazepine (5H-dibenzo[b,f]azepine)-5-carboxamide) (Fig. 1) exhibits $\mathrm{ED}_{50} \mathrm{~s}$ (effective dose in $50 \%$ animals) in MES (maximum electroshock seizures) $7.81 \mathrm{mg} / \mathrm{kg} \mathrm{b.w.} \mathrm{(body} \mathrm{weight)} \mathrm{mice,}$ i.p. and $17 \mathrm{mg} / \mathrm{kg}$ b.w. mice, p.o.(per os) [10, 27] (Table 1). In humans, this iminostilbene derivative is active in simple partial, complex partial, and generalized tonic-clonic seizures, while inactive or deleterious in absence or myoclonic seizures [28]. It is a drug of first choice in the treatment of epilepsy, also during pregnancy. Its monotherapy in mothers during conception causes malformations only in $1.3 \%-8.7 \%$ newborn children up to 1 year of age, if mothers had been taking doses ranging from $<400 \mathrm{mg} /$ day- $1000 \mathrm{mg} /$ day [29].

This AED administered s.c. (subcutaneously) to rats, significantly reduces spontaneous neuronal activity in the Chung model (SNL) at doses $0.5-22.5 \mathrm{mg} / \mathrm{kg}$ b.w. [30]. It is also active in reduction of inflammatory exudate caused by implantation of carrageenan soaked sponges in rats with $\mathrm{ED}_{50}$ of $27.5 \mathrm{mg} / \mathrm{kg}$ b.w. (rats, p.o.) [31], while the anti-inflammatory activity is not necessarily related with the anticonvulsant mechanism of action. The analgesic activity in humans has been widely discussed, since the first report on activity of carbamazepine in trigeminal neuralgia was reported in 1962 by Blom and carbamazepine is now considered a drug of choice for this condition [32,33].

Oxcarbazepine (10,11-dihydro-10-oxo-5H-dibenz[b,f]azepine5-carboxamide) (Fig. 1), a well known 10-oxoderivative of carbamazepine, inhibits voltage-gated sodium channels, which is the main mechanism of action in seizures management. Its additional mechanisms of action, apart from blocking voltage-gated sodium channels, are increase of potassium conductance and modulation of calcium channels. Preclinical evaluation in epilepsy reveals $E_{50}$
$6.1 \mathrm{mg} / \mathrm{kg}$ b.w. in rats, i.p. with $\mathrm{TD}_{50}$ (toxic dose in $50 \%$ animals, measured by rotarod) $40.1 \mathrm{mg} / \mathrm{kg}$ b.w. (rats, i.p.) [34]. More data are presented in Table 1. Oxcarbazepine is a second generation antiepileptic drug with proved efficacy in monotherapy and combination therapy in managing partial epileptic seizures. It is relatively better tolerated than carbamazepine [35].
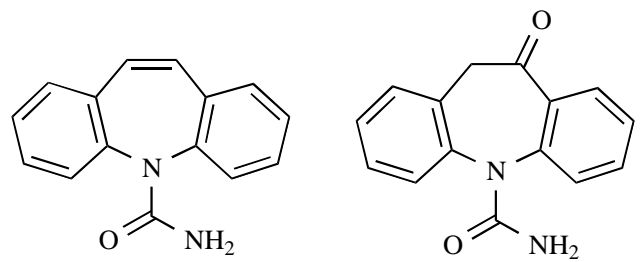

Fig. (1). Chemical structures of carbamazepine and oxcarbazepine.

Oxcarbazepine was proved to be active in the Chung model in a dose-dependent manner, 15 min. after i.p. administration of 10-50 $\mathrm{mg} / \mathrm{kg}$ b.w. (Table 1) [35]. Therefore, it can be effective in various neuropathic pain conditions that are accompanied by allodynia or hyperalgesia. However, it was not proved whether the analgesic activity mechanism depends on $\mathrm{Na}_{\mathrm{V}}$ channels. Other mechanisms related with pain models for carbamazepine and oxcarbazepine are associated with NMDA ( $N$-methyl- $D$-aspartic acid) receptor [31], as well as A1 (adenine) receptor [36] which possibly revitalizes the opioid system [37]. The rationale for use of oxcarbazepine was also discussed in humans and its activity in alleviating pain related with trigeminal neuralgia has been proved, as well as in diabetic neuropathy $[33,38,39]$. However, this drug failed in another study for DNP [40].

Its efficacy at doses $900-2100 \mathrm{mg} /$ day is comparable to carbamazepine taken $400-1200 \mathrm{mg} /$ day in trigeminal neuralgia. Also in clinical trials - oxcarbazepine proved to be better tolerated than carbamazepine as fewer incidents of vertigo, ataxia, dizziness, and fatigue were reported [33].

\section{Lamotrigine}

Lamotrigine (6-(2,3-dichlorophenyl)-1,2,4-triazine-3,5-diamine, LTG) (Fig. 2) is a well known anticonvulsant, whose mechanism of action is basically inhibition of voltage- and use-dependent sodium channels and calcium channels, supported by inhibition of release of excitatory aminoacids. In preclinical tests it proved efficacy in MES at $\mathrm{ED}_{50}=33.2 \mu \mathrm{M} / \mathrm{kg}$ b.w. (mice, i.p.), in $6 \mathrm{~Hz}$ test $\mathrm{ED}_{50}=100.4$ $\mu \mathrm{M} / \mathrm{kg}$ b.w. (mice, i.p., $32 \mathrm{~mA}$ ), in corneal kindling $\mathrm{ED}_{50}=37.1$ $\mu \mathrm{M} / \mathrm{kg}$ b.w. (mice, i.p.) and in hippocampal kindling $\mathrm{ED}_{50}=61.3$ $\mu \mathrm{M} / \mathrm{kg}$ b.w. (rats, i.p.). As hippocampal kindling is a model for epileptogenesis, the AED should slow down development of the disease in patients [41]. Lamotrigine is also active in sound induced seizures (AGS, audiogenic seizures) in Frings mice i.p. with $\mathrm{ED}_{50}$ of $2.39 \mathrm{mg} / \mathrm{kg}$ b.w. $\mathrm{TD}_{50}$ in rotarod test is $30 \mathrm{mg} / \mathrm{kg} \mathrm{b.w.} \mathrm{(mice,} \mathrm{i.p.)}$ and $411 \mathrm{mg} / \mathrm{kg}$ b.w. (rats, p.o.) [42, 43]. Clinical trials in epilepsy show that lamotrigine is similarly effective to carbamazepine. However, it may have a more favorable long-term effect on cognitive function when compared to carbamazepine (in terms of phonemic verbal fluency and stroop color-word interference) [44]. Clinical safety of this AED when used in pregnancy is also comparable to carbamazepine - it causes malformations only in $1.7 \%$ $4.5 \%$ newborn children up to 1 year of age, if mothers had been taking doses ranging from $<300 \mathrm{mg} /$ day- $\geq 300 \mathrm{mg} /$ day [29]. Lamotrigine also can be used in absence seizures in children [45].

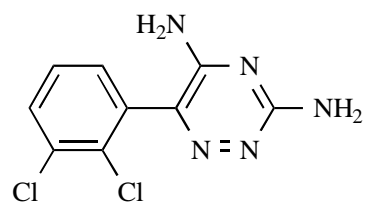

Fig. (2). Chemical structure of lamotrigine. 
Lamotrigine was active in the Chung model with $\mathrm{ED}_{50}$ of 12 $\mathrm{mg} / \mathrm{kg}$ b.w. (originally $47 \mu \mathrm{M} / \mathrm{kg}$ ) rats, p.o. [46], compared to MES $\mathrm{ED}_{50} 1.26 \mathrm{mg} / \mathrm{kg}$ b.w. rats, p.o. and $7.47 \mathrm{mg} / \mathrm{kg}$ mice, i.p. (Table 1).

It is more effective than carbamazepine in clinical trials for use in trigeminal neuralgia. The recommended doses are $25 \mathrm{mg} / \mathrm{day}$, increased by $25 \mathrm{mg}$ every seventh day until the effect or until maximum dose $400 \mathrm{mg} /$ day is achieved [47]. Lamotrigine has been shown to relieve pain associated with DNP, central post-stroke pain and chemotherapy-induced neuropathic pain [48-50]. Additionally, the analgesic efficacy of lamotrigine in the treatment of painful HIV-associated distal sensory polyneuropathy (DSP) was stated [51]. The typical adverse event for this drug is skin rash, and the chance for it increases with the dose. Other side effects are headache and cough [45].

\section{Lacosamide}

Lacosamide (harkoseride, SPM927, ADD 234037, 2(R)acetamido- $N$-benzyl-3-methoxypropionamide) (Fig. 3) exerts activity by means of selective enhancement of slow inactivation of voltage-gated sodium channels [52]. The enantiomer $R$ is active in MES at dose $4.5 \mathrm{mg} / \mathrm{kg}$ b.w. (mice, i.p.) and $3.9 \mathrm{mg} / \mathrm{kg} \mathrm{b.w.} \mathrm{(rats,} \mathrm{i.p.).}$ Lacosamide is also active in audiogenic seizures (Frings mice) and kindling models as well (Table 1) [53]. This AED was found active in cases of partial seizures and in simple motor status epilepticus (with levetiracetam) [54] as well as in refractory nonconvulsive status epilepticus [55].<smiles>COC[C@H](NC(C)=O)C(=O)NCc1ccccc1</smiles>

Fig. (3). Chemical structure of lacosamide.

The analgesic activity of lacosamide has been widely examined. Its only mechanism of action is block of sensory neuronal $\mathrm{Na}_{\mathrm{V}}$ channels, since it does not bind significantly to any of over 50 other targets at $10 \mu \mathrm{M}$ concentration $[15,56]$. Lacosamide proved to be active in models for cancer-related pain [57], in the Chung model $[58,59]$ and the streptozocin model for diabetic neuropathy in the following tests: cold bath test (thermal allodynia), hot plate test (thermal allodynia and hyperalgesia), paw pressure withdrawal test (mechanical hyperalgesia), and brushing test (dynamic allodynia) [60]. The preclinical properties have been subject to other reviews as well [53]. Its activity in inflammatory pain also has been proved in the formalin test, at dose $32 \mathrm{mg} / \mathrm{kg}$ b.w. (mice, i.p.), in the carrageenan-induced thermal and mechanical hyperalgesia in rats (at $32 \mathrm{mg} / \mathrm{kg}$ b.w. and $8 \mathrm{mg} / \mathrm{kg}$ b.w., respectively, i.p.) and adjuvantinduced arthritis in rats (at $40 \mathrm{mg} / \mathrm{kg}$ b.w.) [61].

Consistently with activity in the streptozocin model, lacosamide is also active in DNP in humans with proved efficacy at doses 200$600 \mathrm{mg} /$ day, while its most common adverse events are dizziness, headache, nausea, and - at $600 \mathrm{mg} / \mathrm{day}$ - tremor [62, 63]. Surprisingly, subsequent trials have failed to find an effect [64].

\section{Zonisamide}

Zonisamide (1,2-benzisoxazole-3-methanesulfonamide, ZSM) (Fig. 4) protects against seizures via inhibition of $\mathrm{Na}_{V}$ channels (produces use- and voltage dependent blockade and slows the rate of recovery) as well as T-type calcium channels. Other additional mechanisms have an influence on neurotransmitter systems, i.e. GABAergic (through binding to GABA receptors and influencing GABA transport), dopaminergic and serotoninergic (increasing extracellular levels of dopamine or serotonin), glutaminergic, and cholinergic. It also inhibits carbonic anhydrase, which is too weak to influence its anticonvulsant activity, but affects its pharmacokinetics [65-67].
Consistently with multiplicity of mechanisms of action, ZSM is also active in many animal models, exhibiting $\mathrm{ED}_{50}=19.6 \mathrm{mg} / \mathrm{kg}$ b.w. (mice, p.o.) and $\mathrm{ED}_{50}=7.9 \mathrm{mg} / \mathrm{kg}$ b.w. (rats, p.o.) in MES, activity in hippocampal seizures (rats) and amygdala kindled seizures in rats and in cats [68]. The molecule was developed primarily by Dainippon, recently by Elan and Eisai, and presents broad spectrum activity in clinical trials: adjunct therapy in partial and generalized (tonic-clonic) seizures in adults as well as in monotherapy in children (in Japan) [66, 69].<smiles>NS(=O)(=O)Cc1noc2ccccc12</smiles>

Fig. (4). Chemical structure of zonisamide.

Consistently with multiplicity of mechanisms of action, analgesic activity of ZSM is also diverse. It has been tested in thermal hyperalgesia and mechanical allodynia [70]. Zonisamide is also active in inflammatory and diabetic neuropathic pain. The former was shownwith use of the formalin test, where zonisamide at doses 3 and $10 \mathrm{mg} / \mathrm{kg}$ b.w. (mice) reduced licking behavior in both acute and inflammatory phases of the test. The effect was observed after intrathecal administration as well, and the concluded mechanism of analgesia is probably partially peripheral [20]. Analgesic use in various (not specified) neuropathic pain syndromes in clinics has been reviewed, confirming its activity at doses $100 \mathrm{mg} /$ day [67]. As a consequence of its sulfonamide moiety, the drug is contraindicated in patients with allergies to sulfonamides, and may cause serious side effects such as epidermal necrolysis, Stevens-Johnson syndrome, leucopenia, and aplastic anemia, as well as abnormal thinking, dizziness, nausea, headache, etc. [67].

\section{Topiramate}

Topiramate $\quad(2,3: 4,5$-bis- $O$-(1-methylethylidene)- $\beta$ - $D$-fructopyranose sulfamate, TPM) (Fig. 5) exerts activity via multiple mechanisms. They are inhibition of sodium channels [71] and antagonism of AMPA/kainite ( $\alpha$-amino-3-hydroxy-5-methyl-4isoxazolepropionic acid) receptor [72] as well as enhancement of $\mathrm{GABA}_{\mathrm{A}}$ receptor action, inhibition of L-type calcium channels, and inhibition of carbonic anhydrase (similar to zonisamide, this activity does not contribute to anticonvulsant properties). The activity in MES is supported by $\mathrm{ED}_{50} 15.8 \mathrm{mg} / \mathrm{kg}$ b.w. (rats, p.o.) and 47.6 $\mathrm{mg} / \mathrm{kg}$ b.w. (mice, p.o.) [71]. Moreover, in experimental epilepsy models the $\mathrm{ED}_{50}$ for MES in mice, p.o. is $47.6 \mathrm{mg} / \mathrm{kg} \mathrm{b.w}$. and in rats, p.o. it is $15.8 \mathrm{mg} / \mathrm{kg} \mathrm{b.w}$. The dose $20 \mathrm{mg} / \mathrm{kg}$ has proved effectiveness in neuroprotective studies in the stroke model [73]. It is indicated in partial and generalized seizures, as well as in intractable childhood epilepsies, at doses $125-400 \mathrm{mg}$ /day for children age 2-16 years (not to exceed $800 \mathrm{mg} /$ day) - Lennox-Gastaut Syndrome $\left(\mathrm{ED}_{50}=5.1-5.8 / \mathrm{mg} / \mathrm{kg} /\right.$ day $)$, West syndrome at $15-29$ $\mathrm{mg} / \mathrm{kg} / \mathrm{day}$, and in monotherapy. Adverse events are somnolence, anorexia, fatigue, attention difficulties, aggression and weight loss. Neuropsychiatric events are less frequent in children than in adults, and they can be managed by slow titration [74].

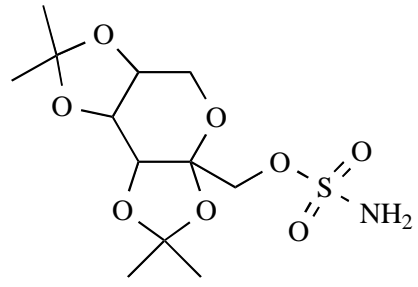

Fig. (5). Chemical structure of topiramate. 
The estimated $\mathrm{ED}_{50}$ for topiramate's anti-allodynic effect is $30 / \mathrm{mg} / \mathrm{kg}$ b.w., rats, i.p. Chronic constriction injury was also performed in rats at $20 \mathrm{mg} / \mathrm{kg}$ b.w., i.p.(Table 1) [73, 75]. Clinical proof of effectiveness in pain indication has been reviewed, describing positive results in clinical trials regarding trigeminal neuralgia (also in multiple sclerosis patients), intercostal neuralgia, and various neuropathic pain syndromes, consistently with CCI models result [67]. Effectiveness in DNP was once proved - the activity was reported at dose range 50-400 $\mathrm{mg} /$ day [76], but in other trials topiramate failed [77]. Most common observed adverse effects are: mild asthenia, dry mouth, irritability, diarrhea, fatigue, sedation, nausea, abdominal cramps, and cognitive impairment [67].

\section{Biaryl Pyrazoles}

A bis-trifluormethyl derivative (1-[3-[2,5-bis(trifluoromethyl) phenyl]phenyl]-5-methyl-pyrazole-3-carboxamide) (Fig. 6) has been selected from the group of molecules tested by Merck. The compound is active in $90 \%$ in MES, mice, p.o. at $10 \mathrm{mg} / \mathrm{kg} \mathrm{b.w}$. [78].

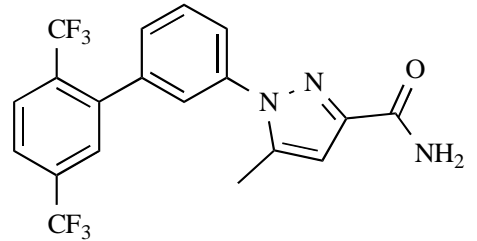

Fig. (6). Chemical structure of 1-[3-[2,5-bis(trifluoromethyl)phenyl] phenyl]-5-methyl-pyrazole-3-carboxamide.

In the spinal nerve ligation model in rats (the Chung model) with binding preferences toward calcium and potassium channels, as well as sodium channels $\left(\mathrm{IC}_{50}\right.$ for $\mathrm{Na}_{\mathrm{V}} 1.7$ of $0.810 \mu \mathrm{M}$ ). The activity in Chung model was measured $2 \mathrm{~h}$ and $4 \mathrm{~h}$ after administration, with 44 and 34\% SNL reversal, respectively [79]. The compound is still in preclinical phase.

\section{Gabapentin}

Gabapentin (1-(aminomethyl)cyclohexaneacetic acid) (Fig. 7) is a GABA derivative. Its main mechanism of action, through binding to $\alpha 2 \delta$ subunit, is inhibition of voltage-gated calcium channels. The additional mechanism is related with the above, i.e. inhibition of glutamate release, relieving neuronal hyperexcitability [80, 81]. It is a well known antiepileptic drug with proved preclinical and clinical efficacy in epilepsy and pain. Its MES $E_{50}$ is $78.2 \mathrm{mg} / \mathrm{kg} \mathrm{b}$.w. (mice, i.p.). It is also active in audiogenic seizures with $\mathrm{ED}_{50}=2.5$ $\mathrm{mg} / \mathrm{kg}$ b.w. (DBA/2J mice, p.o.) and hippocampal kindling with the lowest effective dose $30 \mathrm{mg} / \mathrm{kg}$ b.w. (rats, i.p.), as well as clonic seizure model with use of metrazole (MET) $\mathrm{ED}_{50}=47 \mathrm{mg} / \mathrm{kg}$ b.w. (mice, i.p.) and $52 \mathrm{mg} / \mathrm{kg}$ b.w. (mice, p.o.) [82]. Its clinical efficacy is proved in adjunctive therapy in partial seizures (by Pfizer) at doses $600-1800 \mathrm{mg} /$ day [83, 84], also with paediatric patients [85]. The main adverse event observed is transient drowsiness [84]. It is inconsistent with preclinical efficacy with MET-evoked seizures prevention, that gabapentin is inactive in absence epilepsy (tested in children) [86].

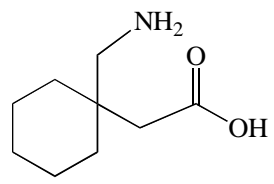

Fig. (7). Chemical structure of gabapentin.

Gabapentinhas become a standard medication for neuropathic pain. However, its analgesic activity is based on a glutamatedependent mechanism in the brainstem (locus coeruleus) [87]. In some reports it is used as a positive control in the SNL model, ad- ministered s.c. to rats $[25,88]$. It significantly reduces spontaneous activity of spinal neurons in the Chung model at doses 10-100 $\mathrm{mg} / \mathrm{kg}$ b.w. [25], while $\mathrm{ED}_{50}$ in another research is $32 \mathrm{mg} / \mathrm{kg}$ b.w. (Table 1) [30]. In most clinical trials gabapentin was used at daily doses of $1200 \mathrm{mg}$ or more - the dosage started at $300 \mathrm{mg} /$ day and was titrated until reaching 1200, 2400, or $3600 \mathrm{mg} /$ day. Many studies for the treatment of neuropathic pain syndromes such as DNP and PHN were successful [89-95]. Additionally, the drug is an effective treatment for cancer-related neuropathic pain [96, 97]. Recently, extended release of gabapentin proved effective and well tolerated for the treatment of diabetic polyneuropathic pain [98].

\section{Retigabine}

Retigabine (D-23129, ethyl $N$-[2-amino-4-[(4-fluorophenyl) methylamino]phenyl]carbamatic acid ethyl ester, ezogabine) (Fig. 8) has been documented to exert its anticonvulsant action via multiple mechanisms. There is evidence indicating that it increases GABAergic transmission in the central nervous system and activates $K_{V} 7$ potassium channels $[81,99,100]$. Such various mechanisms result in broad protection against seizures in MES, ScMET (s.c. metrazol-induced seizures), as well as amygdala kindling model considered as a model for epileptogenesis [101]. The MES $\mathrm{ED}_{50} \mathrm{~s}$ are $9.3 \mathrm{mg} / \mathrm{kg}$ b.w. (mice, i.p.) and $2.9 \mathrm{mg} / \mathrm{kg}$ b.w. (rats, i.p.). Other $\mathrm{ED}_{50} \mathrm{~S}$ are: $13.5 \mathrm{mg} / \mathrm{kg}$ b.w. (ScMET, mice, i.p.), and 18.6 (ScPic, subcutaneous picrotoxin, mice, i.p.) [102]. It was tested in clinics at doses 600 and $900 \mathrm{mg} /$ day as well as 600-1200 mg/day as an adjunctive therapy for partial onset seizures and these doses proved effectiveness [103, 104]. Most commonly reported adverse events were dose-related and included dizziness, somnolence, headache, and fatigue.<smiles>CCOC(=O)Nc1ccc(NCc2ccc(F)cc2)cc1N</smiles>

Fig. (8). Chemical structure of retigabine.

Retigabine has been proved to reduce nociceptive behaviors in rat models of neuropathic pain - chronic constriction injury and spared nerve injury. It also exerts analgesic activity in the formalin test (Table 1) [105, 106]. The assays confirmed antinociceptive activity in models of persistent pain, with concomitant unaffected normal nociceptive sensory processing. This AED has not entered clinical trials for use in pain.

\section{Pregabalin}

Pregabalin (CI-1008, (S)-3-aminomethyl-5-methylhexanoic acid) (Fig. 9), is a derivative of GABA. One of the newest mechanisms found for pregabalin is binding to the $\alpha 2 \delta$ subunit of the calcium channels. Similarly to gabapentin, pregabalin is expected to increase GABA concentration in neuronal tissues. It also enhances activity of glutamate decarboxylase. It is active in MES at $\mathrm{ED}_{50} \mathrm{~s}$ of $20 \mathrm{mg} / \mathrm{kg} \mathrm{b.w}$. (mice, p.o.) and $1.8 \mathrm{mg} / \mathrm{kg} \mathrm{b.w.} \mathrm{(rats,} \mathrm{p.o.).} \mathrm{Activity}$ in audiogenic seizures (Frings mice) also has been proved at doses 3 and $10 \mathrm{mg} / \mathrm{kg}$ b.w. p.o. (Table 1) [101]. A recent review found 38 randomized clinical trials related with pregabalin and its use, with the most common dose of $330 \mathrm{mg}$ (controlled release) [107]. The most typical adverse events included dizziness, vertigo, incoordination, balance disorder, ataxia, diplopia, blurred vision, and sleep disorders [107, 108]. Moreover, pregabalin is contraindicated in juvenile myoclonic epilepsy as it can worsen seizures [109].

Pregabalin is active in the Chung model for mechanical allodynia at doses $3-30 \mathrm{mg} / \mathrm{kg}$ b.w. (rats, p.o.) [110]. Then, numerous controlled clinical trials have shown the efficacy and safety of pregabalin in patients with painful DPN or PHN. In the studies the 
patients who received pregabalin at dosages of $300 \mathrm{mg} /$ day [111 113 ] or $600 \mathrm{mg} /$ day [112-115] experienced significant reductions in pain compared with placebo. Recently, flexible-dose pregabalin $(150-600 \mathrm{mg} /$ day) led to a statistically significant reduction in pain scores in patients with neuropathic pain due to DPN, PHN or posttraumatic nauropathic pain $[116,117]$. Pregabalin 150 to 600 $\mathrm{mg} /$ day was also shown to reduce pain in older patients (age $\geq 65$ years) with neuropathic pain [118].<smiles>CC(C)C[C@@H](CN)CC(=O)O</smiles>

Fig. (9). Chemical structure of pregabalin.

Pregabalin, as Lyrica ${ }^{\mathrm{TM}}$, is marketed for the treatment of peripheral and central neuropathic pain in adults. The treatment can be started at a dose of $150 \mathrm{mg}$ /day for treating neuropathic pain. Based on individual patient response and tolerability, the dosage may be increased to $300 \mathrm{mg} /$ day after an interval of three to seven days, and if needed, to a maximum dose of $600 \mathrm{mg} /$ day after an additional seven-day interval [3].

\section{GABA Modulators}

Influence on GABAergic system can be performed via multiple mechanisms: binding to GABA receptors (ionotropic or metabotropic), enhancement of GABA synthesis through GAD ( $L$ glutamic acid decarboxylase) activation (in case of valproic acid), or inhibition of GABA catabolism:

inhibition of GABA-T ( $\gamma$-aminobutyric acid transaminase) shown by valproic acid and vigabatrin,

inhibition of SSADH (succinic semialdehyde dehydrogenase) by valproic acid, or

inhibition of GAT-1 ( $\gamma$-aminobutyric acid transporter) exhibited by tiagabine [119]. nisms.

As it can be noticed, it usually appears as a mixture of mecha-

\section{Valproic Acid Derivatives}

Valproic acid (2-propylpentanoic acid, VPA) (Fig. 10) acts by a combination of mechanisms related with GABAergic system enhancement (enhancement of activity of GAD resulting in enhanced synthesis of GABA, and inhibiting GABA metabolism - via inhibition of GABA-T and inhibition of SSADH) as well as reduction of NMDA-receptor mediated glutamate excitation, and inhibition of serotonergic system $[119,120]$. Valproic acid is one of the most active anticonvulsants, exhibiting $\mathrm{ED}_{50}$ in MES $485 \mathrm{mg} / \mathrm{kg}$ b.w. (rats, p.o.), or $6 \mathrm{~Hz} \mathrm{ED}_{50}=126$ (mice, i.p.) (with protection index $\mathrm{TD}_{50} / \mathrm{ED}_{50}$ 1.6) [121]. At the same time it is one of the most toxic AEDs (causing hepatotoxicity, teratogenicity, nausea, dizziness, and consequently interactions with other drugs, rash, skin inflammation, etc.).

The role of this drug in neuropathic pain treatment is still unclear. Although Kochar et al., revealed that sodium valproate is well-tolerated, and provides significant subjective improvement in DNP [122, 123], Otto et al. proved that valproic acid has no effect on pain in polyneuropathy [124]. The position of VPA in treatment is so strong that many efforts have been put to develop its second and third generations, in order to limit the side effects, without loss of activity.

Valpromide (2-propylpentanamide, VPD) (Fig. 10), the amide of valproic acid, was synthesized as one of the very first valproic acid derivatives due to premises that teratogenic activity was related with carboxylic group of the molecule. Indeed, valpromide is not teratogenic in VPA-induced teratogenicity model in mice. Valpromide is both active in MES with MES $\mathrm{ED}_{50}=32 \mathrm{mg} / \mathrm{kg}$ b.w. (rats, p.o.) and ScMET $\mathrm{ED}_{50}=59 \mathrm{mg} / \mathrm{kg}$ b.w. (rats, p.o.). It exhibits protection index MES $\mathrm{ED}_{50} / \mathrm{TD}_{50}=2.7$, which shows a more safe, larger therapeutic window than the parent VPA [121].

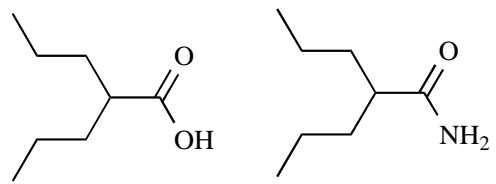

Fig. (10). Chemical structures of valproic acid and valpromide.

Its activity in the SNL model for neuropathic pain is supported by $\mathrm{ED}_{50}=61 \mathrm{mg} / \mathrm{kg}$ b.w. (rats, i.p.) [125].

The close analogs of valpromide constitute valnoctamide and valrocemide ( $N$-valproyl glycinamide, TV 1901) (Fig. 11). An interesting fact can be seen when comparing the anticonvulsant activity of the racemate $(R, S)$ and $2 R, 3 S$ and $2 S, 3 S$ enantiomers of valnoctamide with their analgesic results (Chung model) (Table 1). Racemate seems the optimal configuration for the anticonvulsant activity (MES ED $E_{50} 29 \mathrm{mg} / \mathrm{kg}$ b.w. rats, i.p.), when $2 S, 3 S$ enantiomer is the most active compound in the Chung model, exhibiting $\mathrm{ED}_{50} 39 \mathrm{mg} / \mathrm{kg}$ b.w. (rats, i.p.) [88].

Valnoctamide has not been tested in neuropathic pain in humans.

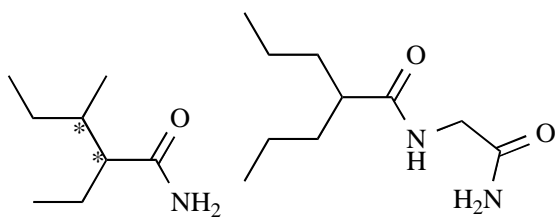

Fig. (11). Chemical structures of valnoctamide and valrocemide.

Valrocemide is a drug candidate in preclinical trials, active in MES with $\mathrm{ED}_{50}$ of $151 \mathrm{mg} / \mathrm{kg}$ b.w. (mice, i.p.), exhibits protection index PI $\left(\mathrm{TD}_{50} / \mathrm{ED}_{50}\right)$ of 2.2. It is also active in ScMet test (mice, i.p.) with $\mathrm{ED}_{50}$ of $132 \mathrm{mg} / \mathrm{kg}$.b.w. The $\mathrm{ED}_{50}$ in rats, p.o. is 73.1 $\mathrm{mg} / \mathrm{kg}$ b.w. in MES (PI>13.7) [126].

Some very interesting discussion can arise from the results of Bialer et al. on stereochemical aspects of structure-activity relationship (Fig. 12). The obtained $R, S-, R-(-)$, and $S$-(+)-propylisopropylacetamide (PID) reveal various activities in MES (i.e. 122, 110, and $145 \mathrm{mg} / \mathrm{kg}$ b.w., respectively) in mice, i.p., and 31,16 , and 25 $\mathrm{mg} / \mathrm{kg}$ b.w., respectively in rats, p.o.[127]. These results show that the most potent enantiomer is the $R$ one. However, from the therapeutic point of view and taking under consideration extrapolation of results into humans, the differences do not necessarily have to be significant $[127,128]$.
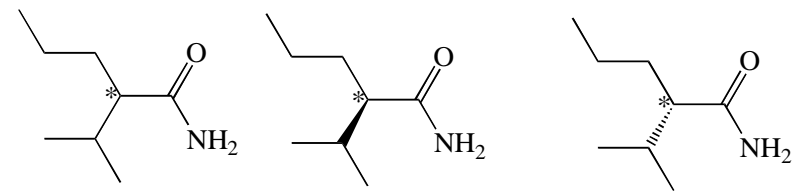

Fig. (12). Chemical structures of racemic PID and its enantiomers $(R, S, R$, and $S$, respectively).

Since valrocemide, other valproic acid derivatives have been developed [25], revealing significant activity in neuropathic pain, with primary anticonvulsant mechanism of action. The design of molecules predicted avoiding teratogenicity and hepatotoxicity the two major disadvantages of the parent compound. The study concerned the following derivatives (Figs. 13 and 14): 
TMCA (2,2,3,3-tetramethylcyclopropanecarboxylic acid),

TMCD (2,2,3,3-tetramethylcyclopropanecarboxamide),

MTMCD ( $N$-methyl-2,2,3,3-tetramethylcyclopropane carboxamide),

TMCU (2,2,3,3-tetramethylcyclopropanecarbonylurea).

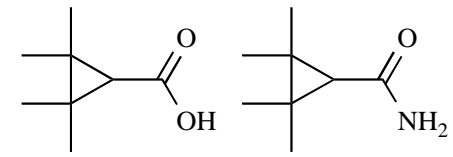

Fig. (13). Chemical structures of TMCA and TMCD.
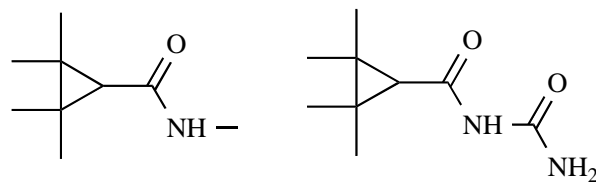

Fig. (14). Chemical structures of MTMCD and TMCU.

They were reported as new valproic acid derivatives. Among them, TMCA showed only weak anticonvulsant activity in rats while others were found to posses broad-spectrum anticonvulsant properties. At the same time all new derivatives: TMCA, TMCD, MTMCD and TMCU showed dose-related antiallodynic activity in SNL model at doses that did not cause motor impairment in the rotarod test [25].

Diisopropylacetamide (DID) (Fig. 15) is another amide derivative of valproic acid that showed antiallodynic activity in the SNL model. The lowest dose of the compound needed to significantly increase the allodynic threshold was $20 \mathrm{mg} / \mathrm{kg}$ (when compared to vehicle) [125].

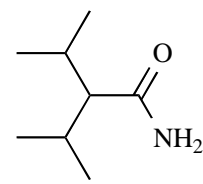

Fig. (15). Chemical structure of DID.

Kaufmann et al. reported in 2009 about a wide series of novel amide, $N$-methyl amide and urea derivatives of valproic acid analogues which consists of 17 compounds [129]. All compounds were tested in MES and ScMet in mice after i.p. administration as well as in SNL model in rats after i.p. administration. Some of them were also evaluated in pilocarpine induced status epilepticus (rats p.o.). The neurotoxicity was evaluated as motor impairment or sedation. Compounds possessed five to nine carbon atoms and some of them additionally carried $\mathrm{N}$-methyl moiety. In this group, compounds which had 8 carbon atoms showed best activity in both antiallodynic as well as in anticonvulsant tests. At the same time compounds with 9 carbon atoms showed narrower safety margin between antiallodynic activity and motor impairment and sedation although they were more potent antiallodynic agents than 8-carbon atoms derivatives. Compounds with fewer than 8 carbon atoms showed the least anticonvulsant and antiallodynic activity. In the presented group the most promising compounds were 3-methyl-2propyl-pentanamide and $N$-carbamoyl-2-ethyl-3-methyl-pentanamide exerting good anticonvulsant properties with $\mathrm{ED}_{50}$ values in pilocarpine test of status epilepticus of $84 \mathrm{mg} / \mathrm{kg}$ (rats, p.o., $0.5 \mathrm{~h}$ ) and $23 \mathrm{mg} / \mathrm{kg}$, respectively (rats, p.o., $0.0 \mathrm{~h}$ ). Moreover, 2isopropyl-3-methyl-pentanamide $\mathrm{ED}_{50} 50 \mathrm{mg} / \mathrm{kg}$. In a test for neuropathic pain the two first compounds exhibit $\mathrm{ED}_{50} 49 \mathrm{mg} / \mathrm{kg}$ b.w. [129].

\section{Tiagabine}

Tiagabine $\quad((R)$-1-[4,4-bis(3-methyl-2-thienyl)-3-butenyl]-3piperidinecarboxylic acid) (Fig. 16) is a derivative of nipecotic acid, used as a hydrochloride, with mechanism of action based on GABA re-uptake inhibition, causing increase of extracellular concentration of GABA. It is more active in ScMET test than in MES, with $\mathrm{ED}_{50} \mathrm{~S}$ $1 \mathrm{mg} / \mathrm{kg}$ b.w. (ScMET, mice, i.p.), $11.5 \mathrm{mg} / \mathrm{kg}$ b.w. (ScMET, rats, i.p.) and $4 \mathrm{mg} / \mathrm{kg}$ b.w. (ScMET, rats, p.o.), compared to $40 \mathrm{mg} / \mathrm{kg}$ b.w. (MES, rats, p.o.) (Table 1). Activity in prevention audiogenic seizures is documented by $\mathrm{ED}_{50} 0.4 \mathrm{mg} / \mathrm{kg}$ b.w. (Frings mice, i.p.) [130]. It is indicated for use in adjunctive therapy for partial seizures [10].

In a clinical trial for efficacy of TGB as add-on therapy in patients with drug resistant focal epilepsy, tiagabine was administered at dose $30-50 \mathrm{mg} / \mathrm{kg}$ as an adjuvant drug to valproic acid or carbamazepine. Beneficial effect of TGB on seizure reduction was seen especially with VA. The most common adverse effects were dizziness and somnolence [131]. Another clinical trial was conducted in patients with refractory epilepsy of whom the mean number of AEDs taken prior to tiagabine was 5. TGB tested at starting dose of 5 or $10 \mathrm{mg} /$ day which was increased another 5 or $10 \mathrm{mg} /$ day every week to achieve the level of $20-40 \mathrm{mg} /$ day. $35 \%$ of patients benefited from the drug, mostly with higher doses. The most common adverse effect was dizziness [132].

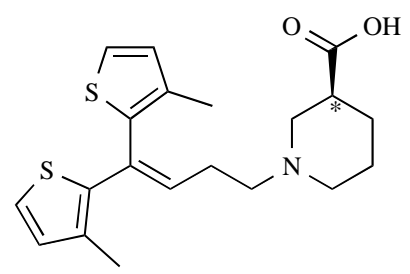

Fig. (16). Chemical structure of tiagabine.

Tiagabine was tested for potential anti-allodynic effects in the nerve ligation (Chung) model of neuropathic pain. The compound showed dose-dependent anti-allodynic and antinociceptive activity in rats, i.p., with significant increases in response threshold to tactile stimulation. In a test for analgesic activity - the formalin test (mice, i.p.) - it was active in both acute and inflammatory phase. Nevertheless, it had no effects on carrageenan-induced edema in the same research [133]. Tiagabine has not been tested in clinical trials for use in neuropathic pain.

\section{Vigabatrin}

Vigabatrin (4-aminohex-5-enoic acid, VGB) (Fig. 17) exerts anticonvulsant mechanism of action based on irreversible inhibition of GABA aminotransferase, resulting in increased amount of GABA in the synapse. Vigabatrin is ineffective in the MES and ScMET tests, but it protects against sound-induced seizures and amygdala kindling in mice. It is also active in seizures induced by kainic acid. Further in clinical trials vigabatrin exhibited some activity in drug resistant complex partial seizures, and in the West syndrome. Therefore, VGB is registered for the therapy of partial (focal, local) epilepsy as well as infantile spasms. Still, the side effects represented by this drug are related with increased concentration of extracellular GABA, including peripheral visual field defect or T2 hyperintensities [65, 134].<smiles>C=CC(N)CCC(=O)O</smiles>

Fig. (17). Chemical structure of vigabatrin.

In order to verify activity of viagabatrin in the Bennett model, a modified procedure of sciatic nerve ligation has been performed 
and the activity was observed at the least $10 \mathrm{mg} / \mathrm{kg} \mathrm{b.w.} \mathrm{(rats,} \mathrm{p.o.).}$ The drug reversed allodynia and hyperalgesia similarly to carbamazepine and valproic acid [135]. The results proved that GABAergic transmission plays role in the mechanism involved in neuropathic pain. More recently, antinociceptive activity of VGB was reported in one of the acute pain models- hot plate test in mice, i.p.[136]. However, no clinical trials considering its activity in patients with neuropathic pain have been reported yet and its potential effectiveness needs to be proved in more advanced studies.

\section{Synaptic Vesicle 2A Binding Drugs}

\section{Levetiracetam}

Levetiracetam, (UCBLO59, (S)- $\alpha$-ethyl-2-oxo-1-pyrolidine acetamide) (Fig. 18) is the $S$ enantiomer of etiracetam, a pyrrolidine derivative with antiepileptic properties. Although the precise mechanism of action of levetiracetam is not fully understood, the drug appears to bind specifically to synaptic vesicle protein $2 \mathrm{~A}$ (SV2A) in both brain and spinal cord [137, 138]. 2A protein inhibits calcium release from intraneuronal stores, opposing the activity of negative modulators of GABA- and glycin-gated currents and inhibiting excessive activity between neurons.

Anticonvulsant properties of levetiracetam are untypical - it is inactive in MES, but active in audiogenic seizures in Frings mice and in $6 \mathrm{~Hz}$ test in mice. In electroshock kindling (mice, i.p.) $\mathrm{ED}_{50}=7 \mathrm{mg} / \mathrm{kg}$ b.w., and in MET kindling $-36 \mathrm{mg} / \mathrm{kg}$ b.w. (mice, i.p.), in pilocarpine-induced seizures $\mathrm{ED}_{50}=7$ (mice, i.p.) [139].<smiles>CC[C@H](C(N)=O)N1CCCC1=O</smiles>

Fig. (18). Chemical structure of levetiracetam.

This AED has been shown to be active in animal models of neuropathic pain. In the chronic constriction injury (Bennett) model the antihyperalgesic effect observed with the compound appeared from a dose of $540 \mathrm{mg} / \mathrm{kg}$ whereas in the diabetic rat model at a dose of $17 \mathrm{mg} / \mathrm{kg}$ (Table 1) [140].

Few clinical trials have been conducted to evaluate effectiveness of levetiracetam in the treatment of neuropathic pain and most of those that have been carried out do not show any benefit in comparison to the use of placebo. Levetiracetam failed to relieve peripheral neuropathic pain in postmastectomy pain syndrome (PMPS) at $3000 \mathrm{mg} /$ day [141], the drug was also ineffective in painful polyneuropathy at the same dose [142] and in patients with spinal cord injury (SCI) at $2000 \mathrm{mg} /$ day [143]. This may result from no evidence that SV2A protein would play a role in neuropathic pain etiopathogenesis.

\section{Brivaracetam}

Brivaracetam (UCB34714, (2S)-2-[(4R)-2-oxo-4-propylpyrrolidin-1-yl]butanamide) (Fig. 19) is a propyl homolog of levetiracetam. Introduction of the propyl moiety changed the ring carbon in position 3 into a chiral one. Brivaracetam, besides binding to synaptic vesicle protein 2A (SV2A) which is its main mechanism [144] also inhibits sodium channels. Just like levetiracetam, this compound is not active in the MES and ScMET tests. Its anticonvulsant activity is supported with $\mathrm{ED}_{50}$ in corneal kindling test $1.2 \mathrm{mg} / \mathrm{kg}$ b.w. (mice, i.p.), in audiogenic seizures $2.4 \mathrm{mg} / \mathrm{kg}$ b.w. (Frings mice, i.p.), and $6 \mathrm{~Hz}$ seizures $4.4 \mathrm{mg} / \mathrm{kg}$ b.w., as well as amygdala kindled mice $68.3 \mathrm{mg} / \mathrm{kg}$ b.w. and corneal kindling at 1.2 $\mathrm{mg} / \mathrm{kg}$ b.w. (mice, i.p.). In amygdala kindled rats it was effective at $\mathrm{ED}_{50} 44 \mathrm{mg} / \mathrm{kg}$ b.w. (i.p.) and $45 \mathrm{mg} / \mathrm{kg}$ b.w. (p.o.) [81].

This drug is being developed by UCB Pharma, after Phase IIb in which it was well tolerated at doses $50-150 \mathrm{mg} / \mathrm{day}$. It was also effective in the treatment of focal epilepsy at $100 \mathrm{mg} /$ day in Phase III trial [81]. However, Phase III clinical trial for monotherapy at doses 50 and $100 \mathrm{mg} /$ day was terminated. An interim analysis revealed that the study was unlikely to attain a positive outcome for the efficacy analysis. No safety concerns were detected [145]. Most common adverse events were: aggression, anxiety, irritability, insomnia, depression, convulsion, headache, somnolence, and dizziness [81].

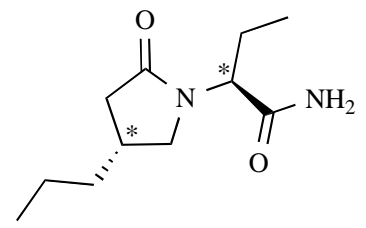

Fig. (19). Chemical structure of brivaracetam.

This AED is also active in CCI models of pain [81] as well asin clinical trials for activity in PHN at $200 \mathrm{mg} /$ day and the study completed in 2010. Unfortunately, no results in humans have been reported until July 2011 [146].

\section{Glutamate Receptor Modulators}

Both NMDA and AMPA receptors have been considered as interesting targets for potential analgesics active in neuropathic pain. Protection against kainic acid - induced currents suggests neuroprotection. On the other hand, activity on NMDA receptor turns the molecule more towards pain indication [147, 148].

\section{CNS-5161 - NMDA Antagonist}

CNS-5161 ( $N$ '-( $N$-(2-chloro-5-(methylmercapto)phenyl)-N'-(3(methylmercapto)phenyl)-N'-methylguanidine hydrochloride) (Fig. 20) is a novel and selective noncompetitive antagonist of the NMDA subset of glutamate receptors in the mammalian brain [149, 150]. Preclinical studies have demonstrated compound's anticonvulsant activity [150].

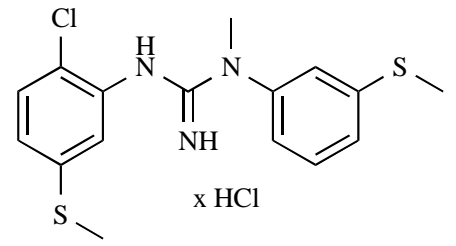

Fig. (20). Chemical structure of CNS-5161.

Consistently with the mechanism of action, the main potential clinical applications of CNS-5161 are analgesia and neuroprotection $[151,152]$. In the safety study it was well tolerated up to the dose $0.5 \mathrm{mg}$ and the most common adverse events were hypertension, headache, and mild visual disorders [151]. The study was not sufficiently powered to study analgesic efficacy, although the activity was observed. The compound is being developed by $\mathrm{CeNeS}$ (Paion, formerly Cambridge NeuroScience) for the potential treatment of neuropathic pain.

\section{NS-1209 - AMPA Antagonist}

NS-1209 (NS-479; SPD-502, [8-methyl-5-(4-( $N, N$-dimethylsulfamoyl)phenyl)-6,7,8,9-tetrahydro- $1 H$-pyrrolo[3,2- $h$ ]-iso-quinoline 2,3-dione-3-O-(4-hydroxybutyric acid-2-yl)oxime] (Fig. 21) is a water-soluble competitive and potent AMPA/ GluR5 (glutamate receptor subtype 5) selective antagonist [153]. NS-1209 has been found to provide strong protection against status epilepticus induced by electrical stimulation of the amygdala or subcutaneous administration of kainic acid in rats, with bolus injection of 50 $\mathrm{mg} / \mathrm{kg}$ b.w. followed by infusion of $5 \mathrm{mg} / \mathrm{kg} * \mathrm{~h}$ (intravenous, $i . v$.). It is interesting, that so far status epilepticus had been associated with 
mechanisms of action like $\mathrm{GABA}_{\mathrm{A}}$ antagonism, $\mathrm{Na}_{\mathrm{V}}$ channels inhibition, NMDA receptor inhibition, or modulation of calcium influx [154]. At infusions dosing $5 \mathrm{mg} / \mathrm{kg} * \mathrm{~h}$ no mortality of animals was observed. Additionally, NS-1209 reveals some neuroprotective activity against status-induced hippocampal neurodegeneration, which, however, was not fully prevented [154].

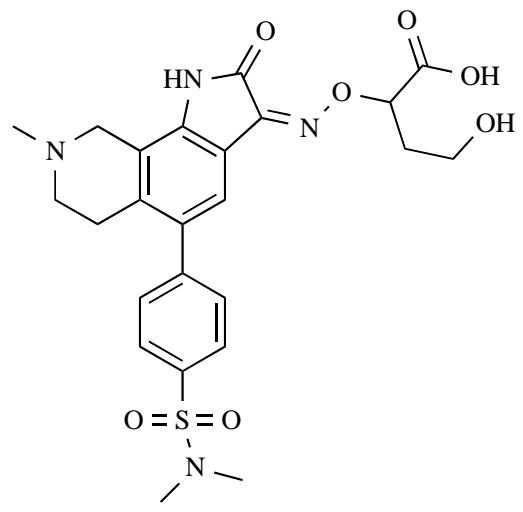

Fig. (21). Chemical structure of NS-1209.

In the chronic constriction injury rat model of neuropathic pain, NS-1209 (3 and $6 \mathrm{mg} / \mathrm{kg}$ b.w., i.p.) exerts reduction of mechanical allodynia and hyperalgesia responses to von Frey hair and pin prick stimulation of the injured hind paw (Table 1). The compound was administered to rats 2-7 weeks after sciatic nerve injury. Additionally, injection of NS-1209 produced attenuation of the cold score response after application of ethyl chloride to the injured hind paw [155]. NS-1209's effect on mechanical allodynia is in accordance with the long-lasting in vivo effects observed in electrophysiological experiments as described previously [153].

In clinical trials, NS-1209 has been shown to possess a long duration of action and is well tolerated by humans at plasma levels two to four times greater than preclinical levels responsible for neuroprotection in rats. Thus, some of the opportunities for the use of NS-1209 may include an adjunct therapy for the prevention of post-operative pain [155]. One clinical study has been completed for use of NS-1209 and lidocaine for patients with peripheral neuropathic pain - the patients were administered $322 \mathrm{mg}$ of NS-1209 and $5 \mathrm{mg}$ of lidocaine. As a result, both drugs were significantly better than placebo in alleviating brush-evoked mechanical allodynia and they both significantly reduced cold allodynia, but in both allodynias NS-1209 did not differ from lidocaine [156].

\section{Indantadol (CHF3381) - NMDA antagonist}

CHF3381 (2-(2,3-dihydro-1H-inden-2-ylamino)acetamide hydrochloride, V3381) (Fig. 22) is a low-affinity, noncompetitive NMDA receptor antagonist and reversible MAO-A (monoaminooxydase) inhibitor. Its MES $\mathrm{ED}_{50}$ in rats, p.o. is $21 \mathrm{mg} / \mathrm{kg} \mathrm{b.w.} \mathrm{It}$ displayed neuroprotective effects after kainate-induced seizures in preclinical studies, and exhibited anticonvulsant and antihyperalgesic activity [157].

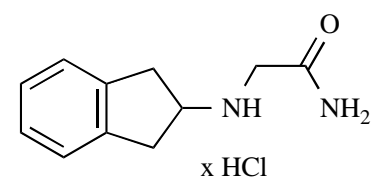

Fig. (22). Chemical structure of indantadol.

The compound was under development by Vernalis plc, under license from Chiesi Farmaceutici SpA, for the treatment of neuropathic pain. It produced a significant suppression of nociceptive behavior and completely blocked mechanical allodynia and hyperalgesia in the capsaicin pain model at 100 and $200 \mathrm{mg} / \mathrm{kg}$ b.w. in rats, p.o. [158]. Indantadol was shown to be active in a variety of rodent models of acute, inflammatory, and neuropathic pain. In rats with a sciatic nerve injury $(\mathrm{CCI})$, indantadol relieved both cold and mechanical allodynia $\left(\mathrm{ED}_{50} 100 \mathrm{mg} / \mathrm{kg}\right.$, rats, p.o.) [159]. Its metabolites are CHF3567 and 2-aminoindane. Its anticonvulsant activity seems stronger than analgesic properties. Still, the analgesic activity in all animal models remains close to the upper limit in the protection gap between $\mathrm{ED}_{50}$ in $\mathrm{MES}$ and $\mathrm{TD}_{50}$ in rotorod=113 $\mathrm{mg} / \mathrm{kg}$ b.w. (Table 1) [160].

One clinical trial has been noticed in a Phase II study on safety, tolerability and efficacy of indantadol in DNP at dose $400 \mathrm{mg}$, but the status of the study has not been updated since 2008 [161].

Tezampanel and NGX-426 - AMPA/Kainate Receptor Antagonists

NGX-426 is the oral ester prodrug of tezampanel (NGX-424, LY293558, (3S,4aR,6R,8aR)-6-[2-(1H-tetrazol-5-yl)ethyl]decahydroisoquinoline-3-carboxylic acid) (Fig. 23), although the structure has not been published. Tezampanel and NGX-426 are ionotropic glutamate receptor antagonists that target the AMPA and kainate subtype receptors. Tezampanel is an anticonvulsant and exhibits neuroprotective activity, which is not surprising, taking into account that AMPA receptors are involved in kindling of the amygdala in mice [162].

Tezampanel was tested in rats for activity after plantar incision at dose $34 \mu \mathrm{mol} / \mathrm{kg}$ (parenteral). It is interesting that tezampanel failed in a clinical trial for analgesic activity, however, it reduced capsaicin-evoked hyperalgesia in humans. Adverse events observed were hazy vision and sedation [163].

NGX-426 is developed for its analgesic activity only. The compound is under development by Raptor Pharmaceutical (previously Torrey Pines Therapeutics) for the potential treatment of neuropathic pain and migraine in male volunteers.<smiles>O=C(O)C1C[C@H]2C[C@H](CCc3nn[nH]n3)CC[C@H]2CN1</smiles>

Fig. (23). Chemical structure of tezampanel.

\section{CONCLUSIONS}

This review shows again that if a drug is active in an animal model, the results cannot be extrapolated to humans directly, and that the risk of failure in clinical trials is significant. Lacosamide can serve as an example, since one clinical trial on DNP failed even though the drug was active in the streptozocin model. This phenomenon is not typical for neuropathic pain, as gabapentin active in MET-evoked seizures in rodents did not show efficacy in absence epilepsy in children.

Considering strategies for drug development, it is already a phenomenon that companies or even researchers turn their drug discovery projects toward a larger market which is pain, due to possible efficacy.These decisions can be seen for e.g. CNS-5161 or NGX-426. One reason stated in the introduction is that hyperexcitability of neurons is both a hallmark for epilepsy and neuropathic pain. The reason coming up from the search of the literature is that efficacy, though not always based on the very same mechanism of action in epilepsy and pain, can be expected. Among older drugs, the data show that $\mathrm{ED}_{50} \mathrm{~s}$ of drugs presented in the review usually stay in the same range in anticonvulsant and analgesic tests. The newest analgesic drugs, however, have been designed in a way that favors specific analgesic and not antiepileptic profile, probably leading to forthcoming separation of the therapeutic groups. 
Table 1. Anticonvulsant and Analgesic Properties of Selected Anticonvulsants

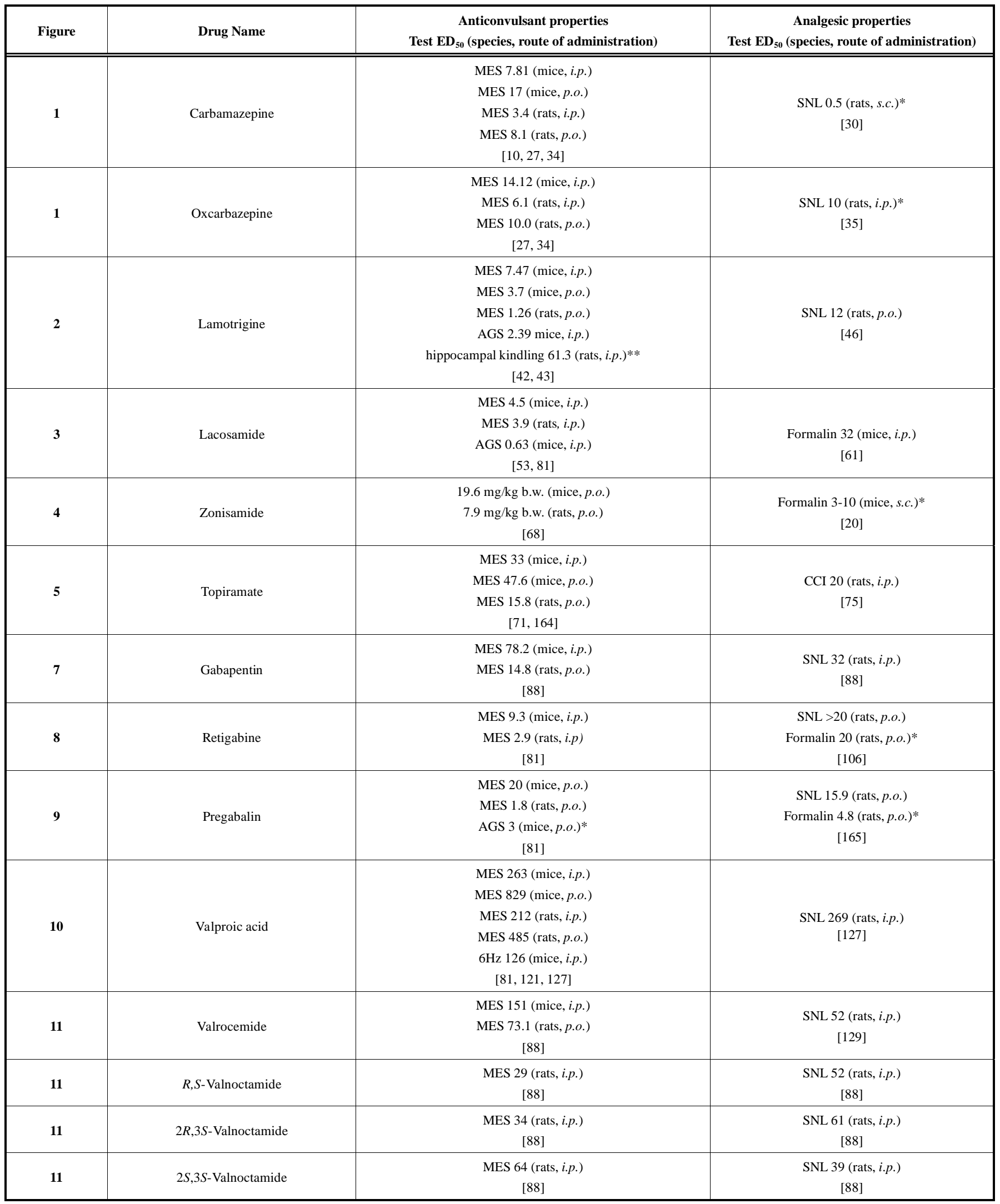


(Table 1). Contd.....

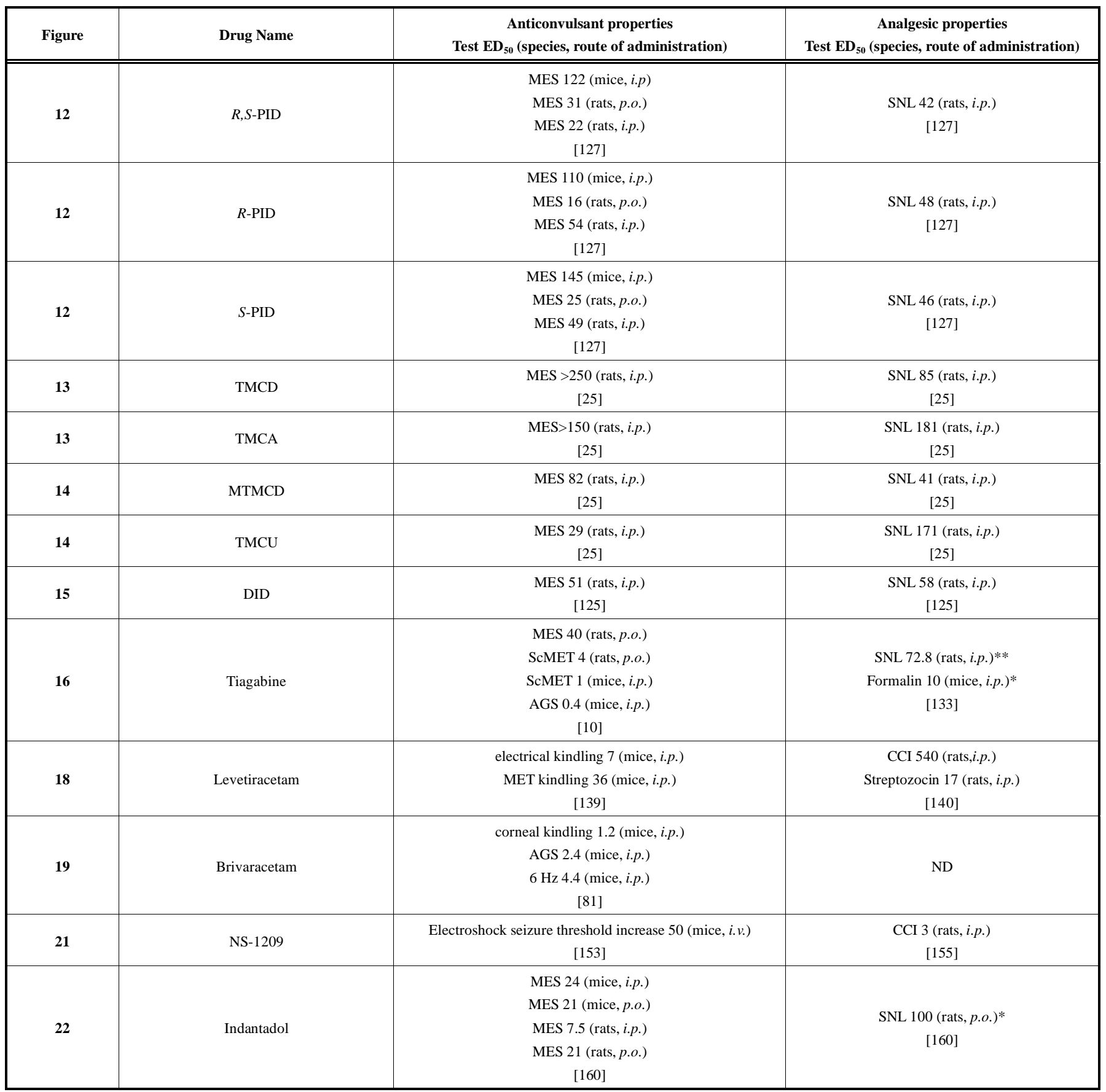

*the result is shown as the minimal effective dose MED as the $\mathrm{ED}_{50}$ was not determined; $* * \mu \mathrm{Mol} / \mathrm{kg}$

MES - maximum electroshock seizures; AGS - audiogenic seizures; SNL - spinal nerve ligation; CCI - chronic constriction injury; ND - not determined; MET - metrazol, pentylenetetrazol.

The probable reason for the above mentioned fact is a significant difference in strategiesfor drug discovery in both indications. Since epileptogenesis is a complex process with various causes and epilepsy has multiple symptoms, discovery of anticonvulsants is still performed by screening in vivo [10]. As a result, the drugs registered on the market exert multiple mechanisms of action and no specificity towards any ion channel/receptor subtype. Even modern AEDs, such as retigabine, though binds to $\mathrm{K}_{\mathrm{V}} 7$ channel, also influences GABA system. On the contrary, analgesics are screened in vitro, for specific targets such as ion channels, i.e. $\mathrm{Na}_{\mathrm{V}} 1.3, \mathrm{Na}_{\mathrm{V}} 1.7$ and $\mathrm{Na}_{\mathrm{V}} 1.8$, or ionotropic glutamate receptors such as NMDA, AMPA, or kainic acid, since the mechanisms of neural damage and induction of neuralgiaare becoming better understood. In such cases there are premises to receive analgesics without anticonvulsant properties, as in the case of e.g.NGX-426. It is also a premise to receive better tolerated drugs, exhibiting fewer side effects. In the end, they are hoped to prove effectiveness in the clinical trials and serve as therapy afterwards.

\section{ACKNOWLEDGEMENTS}

The publication is supported by the European Regional Development Fund through the Innovative Economy Program. 


\section{REFERENCES}

[1] Finnerup, N. B.; Otto, M.; McQuay, H. J.; Jensen, T. S.; Sindrup, S. H. Algorithm for neuropathic pain treatment: an evidence based proposal. Pain, 2005, 118, 289-305.

[2] Zilliox, L.; Russell, J. W. Treatment of diabetic sensory polyneuropathy. Curr. Treat. Options Neurol., 2011, 13, 143-159.

[3] Moore, R. A.; Straube, S.; Wiffen, P. J.; Derry, S.; McQuay, H. J. Pregabalin for acute and chronic pain in adults. Cochrane Database Syst. Rev., 2009, CD007076.

[4] Moore, R. A.; Wiffen, P. J.; Derry, S.; McQuay, H. J. Gabapentin for chronic neuropathic pain and fibromyalgia in adults. Cochrane Database Syst. Rev., 2011, CD007938.

[5] Lunn, M. P.; Hughes, R. A.; Wiffen, P. J. Duloxetine for treating painful neuropathy or chronic pain. Cochrane Database Syst. Rev., 2009, CD007115.

[6] Wiffen, P. J.; Derry, S.; Moore, R. A.; McQuay, H. J. Carbamazepine for acute and chronic pain in adults. Cochrane Database Syst. Rev., 2011, CD005451.

[7] Challapalli, V.; Tremont-Lukats, I. W.; McNicol, E. D.; Lau, J.; Carr, D. B. Systemic administration of local anesthetic agents to relieve neuropathic pain. Cochrane Database Syst. Rev., 2005, CD003345.

[8] Wiffen, P. J.; Rees, J. Lamotrigine for acute and chronic pain. Cochrane Database Syst. Rev., 2007, CD006044.

[9] Eisenberg, E.; McNicol, E.; Carr, D. Opioids for neuropathic pain. Cochrane Database Syst. Rev., 2006, CD006146.

[10] White, S. H.; Woodhead, J. H.; Wilcox, K. S.; Kupferberg, H. J.; Wolf, H. H. In: Antiepileptic Drugs, 5th ed.; Levy, R. H.; Mattson, R. H.; Meldrum, B. S.; Perucca, E. Eds.; Lippincott Williams \& Wilkins: Philadelphia, 2002; pp. 36-48.

[11] Zimmermann, M. Pathobiology of neuropathic pain. Eur. J. Pharmacol., 2001, 429, 23-37.

[12] Costigan, M.; Scholz, J.; Woolf, C. J. Neuropathic pain: a maladaptive response of the nervous system to damage. Annu. Rev. Neurosci., 2009, 32, 132 .

[13] Basbaum, A. I.; Bautista, D. M.; Scherrer, G.; Julius, D. Cellular and molecular mechanisms of pain. Cell, 2009, 139, 267-284.

[14] Dib-Hajj, S. D.; Black, J. A.; Waxman, S. G. Voltage-gated sodium channels: therapeutic targets for pain. Pain Med., 2009, 10, 1260-1269.

[15] Sheets, P. L.; Heers, C.; Stoehr, T.; Cummins, T. R. Differential block of sensory neuronal voltage-gated sodium channels by lacosamide [(2R)-2(acetylamino)-N-benzyl-3-methoxypropanamide], lidocaine, and carbamazepine. J. Pharmacol. Exp. Ther., 2008, 326, 89-99.

[16] Nelson, M. T.; Todorovic, S. M.; Perez-Reyes, E. The role of T-type calcium channels in epilepsy and pain. Curr. Pharm. Des., 2006, 12, 2189-2197.

[17] Schmader, K. E. Epidemiology and impact on quality of life of postherpetic neuralgia and painful diabetic neuropathy. Pain, 2002, 350-354.

[18] Taylor, R. S. Epidemiology of refractory neuropathic pain. Pain Pract., 2006, 6, 22-26.

[19] Kim, K. J.; Yoon, Y. W.; Chung, J. M. Comparison of three rodent neuropathic pain models. Exp. Brain Res., 1997, 113, 200-206.

[20] Tanabe, M.; Murakami, T.; Ono, H. Zonisamide suppresses pain symptoms of formalin-induced inflammatory and streptozotocin-induced diabetic neuropathy. J. Pharmacol. Sci., 2008, 107, 213-220.

[21] Wheeler-Aceto, H.; Porreca, F. The rat paw formalin test: comparison of noxious agents. Pain, 1990, 40, 229-238

[22] Bardin, L. In the formalin model of tonic nociceptive pain, 8-OH-DPAT produces 5-HT1A receptor-mediated, behaviorally specific analgesia. Eur. J. Pharmacol., 2001, 421, 109-114.

[23] Kuner, R. Central mechanisms of pathological pain. Nat. Med., 2010, 16, 1258-1266.

[24] Blackburn-Munro, G.; Erichsen, H. K. Antiepileptics and the treatment of neuropathic pain: evidence from animal models. Curr. Pharm. Des., 2005, $11,2961-2976$.

[25] Winkler, I.; Sobol, E.; Yagen, B.; Steinman, A.; Devor, M.; Bialer, M. Efficacy of antiepileptic tetramethylcyclopropyl analogues of valproic acid amides in a rat model of neuropathic pain. Neuropharmacol, . 2005, 49, 11101120.

[26] Bialer, M.; White, H. S. Key factors in the discovery and development of new antiepileptic drugs. Nat. Rev. Drug Discov., 2010, 9, 68-82.

[27] Zadrożniak, A.; Trojnar, M.; Trojnar, M. Diltiazem enhances the protective activity of oxcarbazepine against maximal electroshock-induced seizures in mice. J. Pre-Clin. Clin. Res., 2008, 2, 147-152.

[28] Brodie, M. J.; Dichter, M. A. Antiepileptic Drugs. N. Engl. J. Med., 1996, 3, 168-175.
[29] Tomson, T.; Battino, D.; Bonizzoni, E.; Craig, J.; Lindhout, D.; Sabers, A.; Perucca, E.; Vajda, F. Dose-dependent risk of malformations with antiepileptic drugs: an analysis of data from the EURAP epilepsy and pregnancy registry. Lancet Neurol., 2011, 10, 609-617.

[30] Chapman, V.; Suzuki, R.; Chamarette, H. L.; Rygh, L. J.; Dickenson, A. H. Effects of systemic carbamazepine and gabapentin on spinal neuronal responses in spinal nerve ligated rats. Pain, 1998, 75, 261-272.

[31] Bianchi, M.; Rossoni, G.; Sacerdote, P.; Panerai, A. E.; Berti, F. Carbamazepine exerts anti-inflammatory effects in the rat. Eur. J. Pharmacol., 1995, 294, 71-74.

[32] Backonja, M. M. Use of anticonvulsants for treatment of neuropathic pain. Neurology2002, 59, S14-S17.

[33] Carrazana, E. Rationale and evidence for the use of oxcarbazepine in neuropathic pain. J. Pain Symptom Manage., 2003, 25, S31-S35.

[34] Benes, J.; Parada, A.; Figueiredo, A.; Alves, P. C.; Freitas, A. P.; Learmonth, D. A.; Cunha, R. A.; Garrett, J.; Soares-da-Silva, P. Anticonvulsant and sodium channel-blocking properties of novel 10, 11-dihydro-5H-dibenz[b, f]azepine-5-carboxamide derivatives. J. Med. Chem., 1999, 42, 2582-2587.

[35] Jang, Y.; Kim, E S.; Park, S. S.; Lee, J.; Moon, D. E. The suppressive effects of oxcarbazepine on mechanical and cold allodynia in a rat model of neuropathic pain. Anesth. Analg. 2005, 101, 800-806.

[36] Fujiwara, Y.; Sato, M.; Otsuki, S. Interaction of carbamazepine and other drugs with adenosine (A1 and A2) receptors. Psychopharmacol., 1986, 90, 332-335.

[37] Mashimoto, S.; Ushijima, I.; Suetsugi, M.; Akimoto, T.; Watanabe, K. Yamada, M. Stress-dependent antinociceptive effects of carbamazepine: A study in stressed and nonstressed rats. Prog. Neuropsychopharmacol. Biol. Psychiatry, 1998, 22, 159-168.

[38] Dogra, S.; Beydoun, S.; Mazzola, J.; Hopwood, M.; Wan, Y. Oxcarbazepine in painful diabetic neuropathy: a randomized, placebo-controlled study. Eur. J. Pain, 2005, 9, 543-554

[39] Beydoun, A.; Shaibani, A.; Hopwood, M.; Wan, Y. Oxcarbazepine in painful diabetic neuropathy: results of a dose-ranging study. Acta Neurologica Scandinavica2006, 113, 395-404

[40] Grosskopf, J.; Mazzola, J.; Wan, Y.; Hopwood, M. A randomized, placebocontrolled study of oxcarbazepine in painful diabetic neuropathy. Acta Neurol. Scand., 2006, 114, 177-180.

[41] Rowley, N. M.; White, H. S. Comparative anticonvulsant efficacy in the corneal kindled mouse model of partial epilepsy: Correlation with other seizure and epilepsy models. Epilepsy Res., 2010, 92, 163-169.

[42] Yamashita, H.; Ohno, K.; Amada, Y.; Hattori, H.; Ozawa-Funatsu, Y.; Toya, T.; Inami, H.; Shishikura, J.; Sakamoto, S.; Okada, M. Effects of 2-[N-(4Chlorophenyl)-N-methylamino]-4H-pyrido[3. 2-e]-1, 3-thiazin-4-one (YM928), an orally active a-amino-3-hydroxy-5-methyl-4isoxazolepropionic acid receptor antagonist, in models of generalized epileptic seizure in mice and rats. J. Pharmacol. Exp. Ther., 2004, 308, 127-133.

[43] Upton, N.; Blackburn, T. P.; Campbell, C. A.; Cooper, D.; Evans, M. L.; Herdon, H. J.; King, P. D.; Ray, A. M.; Stean, T. O.; Chan, W. N.; Evans, J. M.; Thompson, M. Profile of SB-204269, a mechanistically novel anticonvulsant drug, in rat models of focal and generalized epileptic seizures. $B r . J$. Pharmacol., 1997, 121, 1679-1686.

[44] Lee, S. A.; Lee, H. W.; Heo, K.; Shin, D. J.; Song, H. K.; Kim, O. J.; Lee, S. M.; Kim, S. O.; Lee, B. I. Cognitive and behavioral effects of lamotrigine and carbamazepine monotherapy in patients with newly diagnosed or untreated partial epilepsy. Seizure, 2011, 20, 49-54.

[45] Holmes, G. L.; Frank, L. M.; Sheth, R. D.; Philbrook, B.; Wooten, J. D.; Vuong, A.; Kerls, S.; Hammer, A. E.; Messenheimer, J. Lamotrigine monotherapy for newly diagnosed typical absence seizures in children. Epilepsy Res., 2008, 82, 124-132.

[46] Drizin, I.; Gregg, R. J.; Scanio, M. J. C.; Shi, L.; Gross, M. F.; Atkinson, R. N.; Thomas, J. B.; Johnson, M. S.; Carroll, W. A.; Marron, B. E.; Chapman, M. L.; Liu, D.; Krambis, M. J.; Shieh, C. C.; Zhang, X.; Hernandez, G.; Gauvin, D. M.; Mikusa, J. P.; Zhu, C. Z.; Joshi, S.; Honore, P.; Marsh, K. C.; Roeloffs, R.; Werness, S.; Krafte, D. S.; Jarvis, M. F.; Faltynek, C. R.; Kort, M. E. Discovery of potent furan piperazine sodium channel blockers for treatment of neuropathic pain. Bioorg. Med. Chem., 2008, 16, 6379-6386.

[47] Shaikh, S.; Yaacob, H. B.; Abd Rahman, R. B. Lamotrigine for trigeminal neuralgia: Efficacy and safety in comparison with carbamazepine. J. Chin. Med. Assoc., 2011, 74, 243-249.

[48] Eisenberg, E.; Lurie, Y.; Braker, C.; Daoud, D.; Ishay, A. Lamotrigine reduces painful diabetic neuropathy: a randomized, controlled study. Neurology, 2001, 57, 505-509.

[49] Jose, V. M.; Bhansali, A.; Hota, D.; Pandhi, P. Randomized double-blin study comparing the efficacy and safety of lamotrigine and amitriptyline in painful diabetic neuropathy. Diabet. Med., 2007, 24, 377-383. 
[50] Rao, R. D.; Flynn, P. J.; Sloan, J. A.; Wong, G. Y.; Novotny, P.; Johnson, D. B.; Gross, H. M.; Renno, S. I.; Nashawaty, M.; Loprinzi, C. L. Efficacy of lamotrigine in the management of chemotherapy-induced peripheral neuropathy: a phase 3 randomized, double-blind, placebo-controlled trial, N01C3. Cancer, 2008, 112, 2802-2808.

[51] Simpson, D. M.; Olney, R.; McArthur, J. C.; Khan, A.; Godbold, J.; EbelFrommer, K. A placebo-controlled trial of lamotrigine for painful HIVassociated neuropath . Neurology, 2000, 54, 2115-2119.

[52] Errington, A. C.; Sto, T.; Heers, C.; Lees, G. The investigational anticonvulsant lacosamide selectively enhances slow inactivation of voltage-gated sodium channels. Mol. Pharmacol., 2008, 73, 157-169.

[53] Beyreuther, B. K.; Freitag, J.; Heers, C.; Krebsfänger, N.; Scharfenecker, U.; Stöhr, T. Lacosamide: a review of preclinical properties. CNS Drug Rev., 2007, 13, 21-42.

[54] Chen, L. L. K.; Haneef, Z.; Dorsch, A.; Keselman, I.; Stern, J. M. Successful treatment of refractory simple motor status epilepticus with lacosamide and levetiracetam. Seizure, 2011, 20, 263-265.

[55] Koubeissi, M. Z.; Mayor, C. L.; Estephan, B.; Rashid, S.; Azar, N. J. Efficacy and safety of intravenous lacosamide in refractory nonconvulsive status epilepticus. Acta Neurol. Scand., 2011, 123, 142-146.

[56] Errington, A. C.; Coyne, L.; Stöhr, T.; Selve, N.; Lees, G. Seeking a mechanism of action for the novel anticonvulsant lacosamide. Neuropharmacol., 2006, 50, 1016-1029.

[57] Beyreuther, B. K.; Callizot, N.; Brot, M. D.; Feldman, R.; Bain, S. C.; Stöhr, T. Antinociceptive efficacy of lacosamide in rat models for tumor- and chemotherapy-induced cancer pain. Eur. J. Pharmacol., 2007, 565, 98-104.

[58] Bee, L. A.; Dickenson, A. H. Effects of lacosamide, a novel sodium channel modulator, on dorsal horn neuronal responses in a rat model of neuropathy. Neuropharmacol., 2009, 57, 472-479.

[59] Hao, J. X.; Stöhr, T.; Selve, N.; Wiesenfeld-Hallin, Z.; Xu, X. J. Lacosamide, a new anti-epileptic, alleviates neuropathic pain-like behaviors in rat models of spinal cord or trigeminal nerve injury. Eur. J. Pharmacol., 2006, 553, 135140 .

[60] Beyreuther, B.; Callizot, N.; Stöhr, T. Antinociceptive efficacy of lacosamide in a rat model for painful diabetic neuropathy. Eur. J. Pharmacol., 2006, 539, 64-70.

[61] Stöhr, T.; Krause, E.; Selve, N. Lacosamide displays potent antinociceptive effects in animal models for inflammatory pain. Eur. J. Pain, 2006, 10, 241249.

[62] Shaibani, A.; Fares, S.; Selam, J. L.; Arslanian, A.; Simpson, J.; Sen, D.; Bongardt, S. Lacosamide in painful diabetic neuropathy: an 18-week doubleblind placebo-controlled trial. J. Pain, 2009, 10, 818-828.

[63] Rauck, R. L.; Shaibani, A.; Biton, V.; Simpson, J.; Koch, B. Lacosamide in painful diabetic peripheral neuropathy: a phase 2 double-blind placebocontrolled study. Clin. J. Pain, 2007, 23, 150-158.

[64] Ziegler, D.; Hidvégi, T.; Gurieva, I.; Bongardt, S.; Freynhagen, R.; Sen, D.; Sommerville, K. Efficacy and safety of lacosamide in painful diabetic neuropathy. Diabetes Care, 2010, 33, 839-841.

[65] Czapiński, P.; Blaszczyk, B.; Czuczwar, S. J. Mechanisms of action of antiepileptic drugs. Curr. Top. Med. Chem., 2005, 5, 3-14.

[66] Baulac, M. Introduction to zonisamide. Epilepsy Res., 2006, 68, S3-S9.

[67] Guay, D. Oxcarbazepine, topiramate, zonisamide, and levetiracetam: Potential use in neuropathic pain. Am. J. Geriatr. Pharmacother., 2003, 1, 18-37.

[68] Macdonald, R. In: Antiepileptic Drugs, 5th ed.; Levy, R. H.; Mattson, R. H.; Meldrum, B. S.; Perucca, E., Eds.; Lippincott Williams \& Wilkins Healthcare: Philadelphia, 2002; pp. 867-872.

[69] Faught, E. Review of United States and European clinical trials of zonisamide in the treatment of refractory partial-onset seizures. Seizure, $13 \mathrm{Suppl}$ 1, S59-S65.

[70] Hord, A. H.; Denson, D. D.; Chalfoun, A. G.; Azevedo, M. I. The effect of systemic zonisamide (zonegran) on thermal hyperalgesia and mechanical allodynia in rats with an experimental mononeuropathy. Anesth. Analg., 2003, 1700-1706.

[71] Perucca, E. A pharmacological and clinical review on topiramate, a new antiepileptic drug. Pharmacol. Res., 1997, 35, 241-256.

[72] Kaminski, R. M.; Banerjee, M.; Rogawski, M. A. Topiramate selectively protects against seizures induced by ATPA, a GluR5 kainate receptor agonist. Neuropharmacol., 2004, 46, 1097-1104.

[73] Bischofs, S.; Zelenka, M.; Sommer, C. Evaluation of topiramate as an antihyperalgesic and neuroprotective agent in the peripheral nervous system. $J$. Periph. Nerv. Syst., 2004, 9, 70-78.

[74] Ormrod, D.; McClellan, K. Topiramate: a review of its use in childhood epilepsy. Paediatr. Drugs, 2001, 3, 293-319.

[75] Benoliel, R.; Tal, M.; Eliav, E. Effects of topiramate on the chronic constriction injury model in the rat. J. Pain, 2006, 7, 878-883.
[76] Raskin, P.; Donofrio, P. D.; Rosenthal, N. R.; Hewitt, D. J.; Jordan, D. M.; Xiang, J.; Vinik, A. I. Topiramate vs placebo in painful diabetic neuropathy: analgesic and metabolic effects. Neurology, 2004, 63, 865-873.

[77] Thienel, U.; Neto, W.; Schwabe, S. K.; Vijapurkar, U. Topiramate in painful diabetic polyneuropathy: findings from three double-blind placebo-controlled trials. Acta Neurol. Scand., 2004, 110, 221-231.

[78] Tyagarajan, S.; Chakravarty, P. K.; Zhou, B.; Taylor, B.; Fisher, M. H.; Wyvratt, M. J.; Lyons, K.; Klatt, T.; Li, X.; Kumar, S.; Williams, B.; Felix, J.; Priest, B. T.; Brochu, R. M.; Warren, V.; Smith, M.; Garcia, M.; Kaczorowski, G. J.; Martin, W. J.; Abbadie, C.; McGowan, E.; Jochnowitz, N.; Parsons, W. H. Substituted biaryl pyrazoles as sodium channel blockers. Bioorg. Med. Chem. Lett., 2010, 20, 5480-5483.

[79] Tyagarajan, S.; Chakravarty, P. K.; Zhou, B.; Taylor, B.; Eid, R.; Fisher, M. H.; Parsons, W. H.; Wyvratt, M. J.; Lyons, K.; Klatt, T. Discovery of a novel class of biphenyl pyrazole sodium channel blockers for treatment of neuropathic pain. Bioorg. Med. Chem. Lett., 2010, 20, 7479-7482.

[80] Omori, Y.; Kagaya, K.; Enomoto, R.; Sasaki, A.; Andoh, T.; Nojima, H.; Takahata, H.; Kuraishi, Y. A mouse model of sural nerve injury-induced neuropathy: gabapentin inhibits pain-related behaviors and the hyperactivity of wide-dynamic range neurons in the dorsal horn. J. Pharmacol. Sci., 2009 , 109, 532-539.

[81] Bialer, M.; Johannessen, S. I.; Levy, R. H.; Perucca, E.; Tomson, T.; White, H. S. Progress report on new antiepileptic drugs: a summary of the Tenth Eilat Conference (EILAT X). Epilepsy Res., 2010, 92, 89-124.

[82] Taylor, C. P. In Antiepileptic Drugs, 5th ed.; Levy, R. H.; Mattson, R. H.; Meldrum, B. S.; Perucca, E., Eds.; Lippincott Williams \& Wilkins: Philadelphia, 2002; pp. 321-334.

[83] Anhut, H.; Ashman, P.; Feuerstein, T. J.; Sauermann, W.; Saunders, M; Schmidt, B. Gabapentin (neurontin) as add-on therapy in patients with partia seizures: a double-blind, placebo-controlled study. Epilepsia, 1994, 35, 795801.

[84] Sivenius, J.; Kälviäinen, R.; Ylinen, A.; Riekkinen, P. Double-blind study of gabapentin in the treatment of partial seizures. Epilepsia, 1991, 32, 539-542.

[85] Appleton, R.; Fichtner, K.; LaMoreaux, L.; Alexander, J.; Halsall, G.; Murray, G.; Garofalo, E. Gabapentin as add-on therapy in children with refractory partial seizures: a 12-week, multicentre, double-blind, placebocontrolled study. Epilepsia, 1999, 40, 1147-1154.

[86] Trudeau, V.; Myers, S.; LaMoreaux, L.; Anhut, H.; Garofalo, E.; Ebersole, J. Gabapentin in naive childhood absence epilepsy: results from two doubleblind, placebo-controlled, multicenter studies. J. Child. Neurol., 1996, 11 , 470-475.

[87] Hayashida, K. I.; Obata, H.; Nakajima, K.; Eisenach, J. C. Gabapentin acts within the locus coeruleus to alleviate neuropathic pain. Anesthesiology, 2008, 109, 1077-1084.

[88] Kaufmann, D.; Yagen, B.; Minert, A.; Wlodarczyk, B.; Finnell, R. H.; Schurig, V.; Devor, M.; Bialer, M. Evaluation of the antiallodynic, teratogenic and pharmacokinetic profile of stereoisomers of valnoctamide, an amide derivative of a chiral isomer of valproic acid. Neuropharmacol., 2010, $58,1228-1236$

[89] Rowbotham, M.; Harden, N.; Stacey, B.; Bernstein, P.; Magnus-Miller, L. Gabapentin for the treatment of postherpetic neuralgia: a randomized controlled trial. JAMA, 1998, 280, 1837-1842.

[90] Dooley, D. J.; Mieske, C. A.; Borosky, S. A. Inhibition of K(+)-evoked glutamate release from rat neocortical and hippocampal slices by gabapentin. Neurosci. Lett., 2000, 280, 107-110.

[91] Rosenberg, J. M.; Harrell, C.; Ristic, H.; Werner, R. A.; de Rosayro, A. M. The effect of gabapentin on neuropathic pain. Clin. J. Pain, 1997, 13, 251255.

[92] Rice, A. S. C.; Maton, S. Gabapentin in postherpetic neuralgia: a randomised , double blind, placebo controlled study. Pain, 2001, 94, 215-224.

[93] Backonja, M.; Glanzman, R. L. Gabapentin dosing for neuropathic pain: evidence from randomized, placebo-controlled clinical trials. Clin. Ther. 2003, 25, 81-104

[94] Chandra, K.; Shafiq, N.; Pandhi, P.; Gupta, S.; Malhotra, S. Gabapentin versus nortriptyline in post-herpetic neuralgia patients: a randomized, double-blind clinical trial - the GONIP trial. Int. J. Clin. Pharmacol. Ther., 2006, 44, 358-363.

[95] Irving, G.; Jensen, M.; Cramer, M.; Wu, J.; Chiang, Y. K.; Tark, M. Wallace, M. Efficacy and tolerability of gastric-retentive gabapentin for the treatment of postherpetic neuralgia. Clin. J. Pain, 2009, 25, 185-192.

[96] Caraceni, A.; Zecca, E.; Bonezzi, C.; Arcuri, E.; Yaya Tur, R.; Maltoni, M. Visentin, M.; Gorni, G.; Martini, C.; Tirelli, W.; Barbieri, M.; De Conno, F. Gabapentin for neuropathic cancer pain: a randomized controlled trial from the gabapentin cancer pain study group. J. Clin. Oncol., 2004, 22, 29092917. 
[97] Ross, J. R.; Goller, K.; Hardy, J.; Riley, J.; Broadley, K.; A'Hern, R.; Williams, J. Gabapentin is effective in the treatment of cancer-related neuropathic pain: a prospective, open-label study. J. Palliat. Med., 2005, 8, 11181126.

[98] Sandercock, D.; Cramer, M.; Wu, J.; Chiang, Y. K.; Biton, V.; Heritier, M. Gabapentin extended release for the treatment of painful diabetic peripheral neuropathy: efficacy and tolerability in a double-blind, randomized, controlled clinical trial. Diabetes Care2009, 32, e20.

[99] Rundfeldt, C. The new anticonvulsant retigabine (D-23129) acts as an opener of $\mathrm{K}+$ channels in neuronal cells. Eur. J. Pharmacol., 1997, 336, 2432424329.

[100] Rundfeldt, C.; Netzer, R. The novel anticonvulsant retigabine activates Mcurrents in Chinese hamster ovary-cells tranfected with human KCNQ2/3 subunits. Neurosci. Lett. 2000, 282, 73-76.

[101] Bialer, M.; Johannessen, S. I.; Kupferberg, H. J.; Levy, R. H.; Loiseau, P.; Perucca, E. Progress report on new antiepileptic drugs: a summary of the fourth Eilat conference (EILAT IV). Epilepsy Res., 1999, 34, 1-41.

[102] Blackburn-Munro, G.; Dalby-Brown, W.; Mirza, N. R.; Mikkelsen, J. D.; Blackburn-Munro, R. E. Retigabine: chemical synthesis to clinical application. CNS Drug Rev., 2005, 11, 1-20.

[103] Brodie, M. J.; Lerche, H.; Gil-Nagel, A.; Elger, C.; Hall, S.; Shin, P.; Nohria, V.; Mansbach, H. Efficacy and safety of adjunctive ezogabine (retigabine) in refractory partial epilepsy. Neurology, 2010, 75, 1817-1824.

[104] Owen, R. T. Ezogabine: a novel antiepileptic as adjunctive therapy for partial onset seizures. Drugs Today, 2010, 46, 815-822.

[105] Munro, G.; Erichsen, H. K.; Mirza, N. R. Pharmacological comparison of anticonvulsant drugs in animal models of persistent pain and anxiety. Neuropharmacol., 2007, 53, 609-618.

[106] Blackburn-Munro, G. The anticonvulsant retigabine attenuates nociceptive behaviours in rat models of persistent and neuropathic pain. Eur. J. Pharmacol., 2003, 460, 109-116.

[107] Zaccara, G.; Gangemi, P.; Perucca, P.; Specchio, L. The adverse event profile of pregabalin: A systematic review and meta-analysis of randomized controlled trials. Epilepsia, 2011, 52, 826-836.

[108] Ryvlin, P.; Kälviäinen, R.; Von Raison, F.; Giordano, S.; Emir, B.; Chatamra, K. Pregabalin in partial seizures: a pragmatic 21-week, open-label study (PREPS). Eur. J. Neurol., 2010, 17, 726-732.

[109] Mantoan, L.; Walker, M. Treatment options in juvenile myoclonic epilepsy. Curr. Treat. Options Neurol., 2011, 13, 1-16.

[110] Field, M. J.; Bramwell, S.; Hughes, J.; Singh, L. Detection of static and dynamic components of mechanical allodynia in rat models of neuropathic pain: are they signalled by distinct primary sensory neurones? Pain, 1999, 83, 303-311.

[111] Rosenstock, J.; Tuchman, M.; Lamoreaux, L.; Sharma, U. Pregabalin for the treatment of painful diabetic peripheral neuropathy: a double-blind, placebocontrolled trial. Pain, 2004, 110, 628-638.

[112] van Seventer, R.; Feister, H. A.; Young, J. P. J.; Stroker, M.; Versavel, M.; Rigaudy, L. Efficacy and tolerability of twice-daily pregabalin for treating pain and related sleep interference in postherpetic neuralgia: a 13-week, randomized trial. Curr. Med. Res. Opin., 2006, 22, 375-384.

[113] Satoh, J.; Yagihashi, S.; Baba, M.; Suzuki, M.; Arakawa, A.; Yoshiyama, T.; Shoji, S. Efficacy and safety of pregabalin for treating neuropathic pain associated with diabetic peripheral neuropathy: a 14 week, randomized, doubleblind, placebo-controlled trial. Diabet. Med., 2011, 28, 109-116.

[114] Tölle, T.; Freynhagen, R.; Versavel, M.; Trostmann, U.; Young, J. P. Pregabalin for relief of neuropathic pain associated with diabetic neuropathy: a randomized, double-blind study. Eur. J. Pain, 2008, 12, 203-213.

[115] Arezzo, J. C.; Rosenstock, J.; Lamoreaux, L.; Pauer, L. Efficacy and safety of pregabalin $600 \mathrm{mg} / \mathrm{d}$ for treating painful diabetic peripheral neuropathy: a double-blind placebo-controlled trial. BMC Neurology, 2008, 8, 33-46.

[116] Moon, D. E.; Lee, D. I.; Lee, S. C.; Song, S. O.; Yoon, D. M.; Yoon, M. H.; Kim, H. K.; Lee, Y. W.; Kim, C.; Lee, P. B. Efficacy and tolerability of pregabalin using a flexible, optimized dose schedule in Korean patients with peripheral neuropathic pain: a 10 -week, randomized, double-blind, placebocontrolled, multicenter study. Clin. Ther., 2010, 32, 2370-2385.

[117] Guan, Y.; Ding, X.; Cheng, Y.; Fan, D.; Tan, L.; Wang, Y.; Zhao, Z.; Hong, Z.; Zhou, D.; Pan, X.; Chen, S.; Martin, A.; Tang, H.; Cui, L. Efficacy of pregabalin for peripheral neuropathic pain: results of an 8-week, flexibledose, double-blind, placebo-controlled study conducted in China. Clin. Ther, 2011, 33, 159-166

[118] Semel, D.; Murphy, T. K.; Zlateva, G.; Cheung, R.; Emir, B. Evaluation of the safety and efficacy of pregabalin in older patients with neuropathic pain: results from a pooled analysis of 11 clinical studies. BMC Fam. Pract., 2010, $11,85-97$

[119] Johannessen, C. U. Mechanisms of action of valproate: a commentatory. Neurochem. Int., 2000, 37, 103-110.
[120] Löscher, W. Basic pharmacology of valproate: a review after 35 years of clinical use for the treatment of epilepsy. CNS Drug, s2002, 16, 669-694.

[121] Shimshoni, J. A.; Bialer, M.; Wlodarczyk, B.; Finnell, R. H.; Yagen, B. Potent anticonvulsant urea derivatives of constitutional isomers of valproic acid. J. Med. Chem., 2007, 50, 6419-6427.

[122] Kochar, D. K.; Rawat, N.; Agrawal, R. P.; Vyas, A.; Beniwal, R.; Kochar, S. K.; Garg, P. Sodium valproate for painful diabetic neuropathy: a randomized double-blind placebo-controlled study. QJM, 2004, 97, 33-38.

[123] Kochar, D. K.; Jain, N.; Agarwal, R. P.; Srivastava, T.; Agarwal, P.; Gupta, $\mathrm{S}$. Sodium valproate in the management of painful neuropathy in type $2 \mathrm{dia}-$ betes - a randomized placebo controlled study. Acta Neurol. Scand., 2002, $106,248-252$

[124] Otto, M.; Bach, F. W.; Jensen, T. S.; Sindrup, S. H. Valproic acid has no effect on pain in polyneuropathy: a randomized, controlled trial. Neurology, 2004, 62, 285-288.

[125] Winkler, I.; Blotnik, S.; Shimshoni, J.; Yagen, B.; Devor, M.; Bialer, M. Efficacy of antiepileptic isomers of valproic acid and valpromide in a rat model of neuropathic pain. Br. J. Pharmacol., 2005, 146, 198-208.

[126] Isoherranen, N.; Woodhead, J. H.; White, H. S.; Bialer, M. Anticonvulsant profile of valrocemide (TV1901): a new antiepileptic drug. Epilepsia, 2001, 42, 831-836.

[127] Kaufmann, D.; Yagen, B.; Minert, A.; Tal, M.; Devor, M.; Bialer, M. Evaluation of the enantioselective antiallodynic and pharmacokinetic profile of propylisopropylacetamide, a chiral isomer of valproic acid amide. Neuropharmacol., 2008, 54, 699-707.

[128] Spiegelstein, O.; Yagen, B.; Levy, R. H.; Finnell, R. H.; Bennett, G. D.; Roeder, M.; Schurig, V.; Bialer, M. Stereoselective pharmacokinetics and pharmacodynamics of propylisopropyl acetamide, a CNS-active chiral amide analog of valproic acid. Pharm. Res., 1999, 16, 1582-1588.

[129] Kaufmann, D.; Bialer, M.; Shimshoni, J. A.; Devor, M.; Yagen, B. Synthesis and evaluation of antiallodynic and anticonvulsant activity of novel amide and urea derivatives of valproic acid analogues. J. Med. Chem., 2009, 52, 7236-7248.

[130] Fink-Jensen, A.; Suzdak, P. D.; Swedberg, M. D.; Judge, M. E.; Hansen, L.; Nielsen, P. G. The gamma-aminobutyric acid (GABA) uptake inhibitor, tiagabine, increases extracellular brain levels of GABA in awake rats. Eur. J. Pharmacol., 1992, 220, 197-201.

[131] Jedrzejczak, J. Tiagabine as add-on therapy may be more effective with valproic acid - open label , multicentre study of patients with focal epilepsy. Eur. J. Neurol., 2005, 12, 176-180.

[132] McKee, P. Treating refractory epilepsy with tiagabine: clinical experience. Seizure, 2004, 13, 478-480.

[133] Giardina, W. J.; Decker, M. W.; Porsolt, R. D.; Roux, S.; Collins, S. D.; Kim, D. J. B.; Bannon, A. W. An evaluation of the GABA uptake blocker tiagabine in animal models of neuropathic and nociceptive pain. Drug Dev. Res., 1998, 44, 106-113.

[134] James Willmore, L.; Abelson, M. B.; Ben-Menachem, E.; Pellock, J. M.; Donald Shields, W. Vigabatrin: 2008 update. Epilepsia, 2009, 50, 163-173.

[135] Alves, N. D.; de Castro-Costa, C. M.; de Carvalho, A. M.; Santos, F. J.; Silveira, D. G. Possible analgesic effect of vigabatrin in animal experimental chronic neuropathic pain. Arq. Neuropsiquiatr., 1999, 57, 916-920.

[136] Luszczki, J. J.; Czuczwar, S. J. Dose-response relationship analysis of vigabatrin doses and their antinociceptive effects in the hot-plate test in mice. Pharmacol. Rep., 2008, 60, 409-414.

[137] Fuks, B.; Gillard, M.; Michel, P.; Lynch, B.; Vertongen, P.; Leprince, P.; Klitgaard, H.; Chatelain, P. Localization and photoaffinity labelling of the levetiracetam binding site in rat brain and certain cell lines. Eur. J. Pharmacol., 2003, 478, 11-19.

[138] Lambeng, N.; Gillard, M.; Vertongen, P.; Fuks, B.; Chatelain, P. Characterization of $[(3) \mathrm{H}]$ ucb 30889 binding to synaptic vesicle protein $2 \mathrm{~A}$ in the rat spinal cord. Eur. J. Pharmacol., 2005, 520, 70-76.

[139] Klitgaard, H.; Matagne, A.; Gobert, J.; Wülfert, E. Evidence for a unique profile of levetiracetam in rodent models of seizures and epilepsy. Eur. J. Pharmacol., 1998, 353, 191-206.

[140] Ardid, D.; Lamberty, Y.; Alloui, A.; Coudore-Civiale, M A.; Klitgaard, H.; Eschalier, A. Antihyperalgesic effect of levetiracetam in neuropathic pain models in rats. Eur. J. Pharmacol., 2003, 473, 27-33.

[141] Vilholm, O. J.; Cold, S.; Rasmussen, L.; Sindrup, S. H. Effect of levetiracetam on the postmastectomy pain syndrome. Eur. J. Neurol., 2008 , 15, 851-857.

[142] Holbech, J. V.; Otto, M.; Bach, F. W.; Jensen, T. S.; Sindrup, S. H. The anticonvulsant levetiracetam for the treatment of pain in polyneuropathy: randomized, placebo-controlled, cross-over trial. Eur. J. Pain, 2011, 15, 608614. 
[143] Finnerup, N. B.; Grydehøj, J.; Bing, J.; Johannesen, I. L.; Biering-Sørensen, F.; Sindrup, S. H.; Jensen, T. S. Levetiracetam in spinal cord injury pain: a randomized controlled trial. Spinal Cord, 2009, 47, 861-867.

[144] Rogawski, M. A.; Bazil, C. W. New molecular targets for antiepileptic drugs: $\alpha 2 \delta$, SV2A, and Kv7/KCNQ/M potassium channels. Curr. Neurol. Neurosci. Rep., 2008, 8, 345-352.

[145] Schulze-Bonhage, A. Brivaracetam for the treatment of epilepsy. Expert Opin. on Pharmacother., 2011, [Epub ahead of print].

[146] A study assessing efficacy of brivaracetam in subjects with persistent pain after shingles (post-herpetic neuralgia). http://clinicaltrials. gov/ct2/show/ NCT00160667?term=brivaracetam \& rank $=8$ (Accessed July 14, 2011).

[147] Parsons, C. G. NMDA receptors as targets for drug action in neuropathic pain. Eur. J. Pharmacol., 2001, 429, 71-78

[148] Garry, E. Specific involvement in neuropathic pain of AMPA receptors and adapter proteins for the GluR2 subunit. Mol. Cell. Neurosci., 2003, 24, 1022 .

[149] Walters, M. R.; Bradford, A. P. J.; Fischer, J.; Lees, K. R. Early clinical experience with the novel NMDA receptor antagonist CNS 5161. Br. J. Clin. Pharmacol., 2002, 53, 305-311.

[150] Hu, L. Y.; Guo, J.; Magar, S. S.; Fischer, J. B.; Burke-Howie, K. J.; Durant, G. J. Synthesis and pharmacological evaluation of N-(2, 5-disubstituted phenyl)-N'-(3-substituted phenyl)-N'-methylguanidines as N-methyl-Daspartate receptor ion-channel blockers. J. Med. Chem., 1997, 40, 42814289

[151] Forst, T.; Smith, T.; Schütte, K.; Marcus, P.; Pfützner, A. Dose escalating safety study of CNS $5161 \mathrm{HCl}$, a new neuronal glutamate receptor antagonist (NMDA) for the treatment of neuropathic pain. Br. J. Clin. Pharmacol., 2007, 64, 75-82.

[152] Danysz, W.; Parsons, C. G. Neuroprotective potential of ionotropic glutamate receptor antagonists. Neurotox. Res., 2002, 4, 119-126.

[153] Nielsen, E. O.; Varming, T.; Mathiesen, C.; Jensen, L. H.; Moller, A.; Gouliaev, A. H.; Wätjen, F.; Drejer, J. SPD 502: a water-soluble and in vivo longlasting AMPA antagonist with neuroprotective activity. J. Pharmacol. Exp. Ther., 1999, 289, 1492-1501.

[154] Pitkänen, A.; Mathiesen, C.; Rønn, L. C. B.; Møller, A.; Nissinen, J. Effect of novel AMPA antagonist, NS1209, on status epilepticus. An experimental study in rat. Epilepsy Res., 2007, 74, 45-54.

[155] Blackburn-Munro, G.; Bomholt, S. F.; Erichsen, H. K. Behavioural effects of the novel AMPA/GluR5 selective receptor antagonist NS1209 after systemic administration in animal models of experimental pain. Neuropharmacol., 2004, 47, 351-362.

[156] Gormsen, L.; Finnerup, N. B.; Almqvist, P. M.; Jensen, T S. The efficacy of the AMPA receptor antagonist NS1209 and lidocaine in nerve injury pain: a randomized, double-blind, placebo-controlled, three-way crossover study. Anesth. Analg., 2009, 108, 1311-1319.

[157] Mattia, C.; Coluzzi, F. Indantadol, a novel NMDA antagonist and nonselective MAO inhibitor for the potential treatment of neuropathic pain. IDrugs, 2007, 10, 636-644.

[158] Bassani, F.; Bergamaschi, M.; Tonino Bolzoni, P.; Villetti, G. CHF3381, a novel antinociceptive agent, attenuates capsaicin-induced pain in rats. Eur. $J$. Pharmacol., 2005, 519, 231-236.

[159] Villetti, G.; Bergamaschi, M.; Bassani, F.; Bolzoni, P. T.; Maiorino, M.; Pietra, C.; Rondelli, I.; Chamiot-Clerc, P.; Simonato, M.; Barbieri, M. Antinociceptive activity of the N-methyl-D-aspartate receptor antagonist $\mathrm{N}-(2$ Indanyl)-glycinamide hydrochloride (CHF3381) in experimental models of inflammatory and neuropathic pain. J. Pharmacol. Exp. Ther., 2003, 306, 804-814.

[160] Villetti, G.; Bregola, G.; Bassani, F.; Bergamaschi, M.; Rondelli, I.; Pietra, C.; Simonato, M. Preclinical evaluation of CHF3381 as a novel antiepileptic agent. Neuropharmacol., 2001, 40, 866-878.

[161] Study of the safety, tolerability and efficacy of V3381 in patients with diabetic peripheral neuropathic pain. http://clinicaltrials. gov/ct2/show/ NCT00794430 (Accessed July 15, 2011)

[162] Rogawski, M. A.; Kurzman, P. S.; Yamaguchi, S.; Li, H. Role of AMPA and GluR5 kainate receptors in the development and expression of amygdala kindling in the mouse. Neuropharmacol., 2000, 40, 28-35.

[163] Sang, C. N.; Hostetter, M. P.; Gracely, R. H.; Chappell, A. S.; Schoepp, D. D.; Lee, G.; Whitcup, S.; Caruso, R.; Max, M. B. AMPA/kainate antagonist LY293558 reduces capsaicin-evoked hyperalgesia but not pain in normal skin in humans. Anesthesiology, 1998, 89, 1060-1067.

[164] Perucca, E. What is the promise of new antiepileptic drugs in status epilepticus? Focus on brivaracetam, carisbamate, lacosamide, NS-1209, and topiramate. Epilepsia, 2009, 50 Suppl 1, 49-50

[165] Gustafsson, H.; Sandin, J. Oral pregabalin reverses cold allodynia in two distinct models of peripheral neuropathic pain. Eur. J. Pharmacol., 2009, 605, 103-108.
Received: May 06, $2011 \quad$ Revised: July 15, $2011 \quad$ Accepted: July 17, 2011 